University of Louisville

ThinkIR: The University of Louisville's Institutional Repository

Electronic Theses and Dissertations

1937

\title{
The seventh-grade arithmetic textbook and modern educational thought.
}

Adele Hunckler 1904-1997

University of Louisville

Follow this and additional works at: https://ir.library.louisville.edu/etd

Part of the Educational Methods Commons, and the Science and Mathematics Education Commons

\section{Recommended Citation}

Hunckler, Adele 1904-1997, "The seventh-grade arithmetic textbook and modern educational thought." (1937). Electronic Theses and Dissertations. Paper 1812.

https://doi.org/10.18297/etd/1812

This Master's Thesis is brought to you for free and open access by ThinkIR: The University of Louisville's Institutional Repository. It has been accepted for inclusion in Electronic Theses and Dissertations by an authorized administrator of ThinkIR: The University of Louisville's Institutional Repository. This title appears here courtesy of the author, who has retained all other copyrights. For more information, please contact thinkir@louisville.edu. 
TNIVERSITY OF LOUISVILIE

THE SEVENTH-GRADE ARITHMETIC TEXTBOOK

AND

MODERN FDUCATIONAL THOUGHI

\author{
A Disertation \\ submitted to the Faculty \\ of the Graduate school of the Dniversity of Loulavi12e \\ In Partial Fulfiliment of the \\ Requirements for the Degree \\ of laster of Arts
}

Department of Education

By

Ade 1e Hunclezer

Year

1937 
NAME

TIIIE THE SEVENIE-GRADE ARITHMETIC TEXTBOOK

AND MODERN EDUCATIONAI THOUGHI

DIRECTOR

APPROVED BY:

DIRECTOR

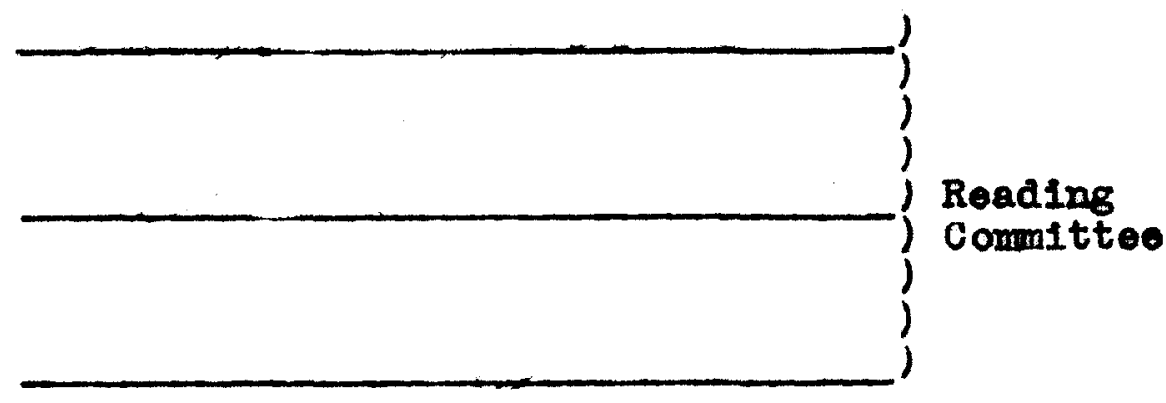

Representative

of the Bnglish

Department

DATE_Sple 22,1937 
TABIE OF CONIENT'S

Chapter

Page

I Introduction.................... I

II How Textbooks Are selected............. 10

III Standards for the Modern Seventh-Grade Arithmet 1e liextbook.................. 18

Iv Analyses of Six Modern Seventh-Grade Arithmet1c 'lextbooks................ 63

V Summary and hecommendations.......... 104

Appondix

A Excerpts from the Six Books Chosen

for Vocabulary Analya1s............ 117

B Illustrations of How Integration Is Attempted in the Six Books Analyzed... 127

C Instructions Used by the Judges in Rating six serenth-Crade Arithmotio 'lextbooks as to Adequacy With Which 'they Conform to Requirements of Modern Educational thought.......... 138 
CHAPTER I

INTRODUCTIOA

The funior high sohool morement in tho

Bnited states has developed during the present

century. Daring that tiw it has grom unt1l such witers as Koos now prodict that it will bo a noarunirersal institution within the next twenty-rive or thirty jears. I Leaders of present-day oduoational thought realize that the funior high school offors a problem in eduoational thoory and practioe that mast bo given major attention. Ihis is partioularis true of the ourrieulim of whioh the toxtbook forms an approciablo part.

the rapid growth of the junior high sohool, the rovolutionary odueational theorios upon which it Is founded, the lag of oducational tools as against demonstrated noed, and tho scoming social necossity for this adminiatrativo unit, all call for sourching Investigations in the fleld. The purpose of the present atudy is to throw some light upon textbook

Irilliams, R. L., "The Selection of Mathomatics Textbooks in Junlor High School." Sahool and Solence, Volumo V, Humber 3, March, 1931, Pp. 284-291. 
practices and noods at the soventh-grade lovel. An attempt is made to answer the following questlons:

1. What are tho characteristics of a modern seventhgrade arithmotic textbook in terma of modern oducational and paschologioal thought?

2. Hor adequately do cortain of tho recont sovonthgrade arithmotic textbooks conform to these standards?

3. How might a oity such as Loulavillo Inswre that the arithmotio textbook at the sevonth-grade lovel providos its obilaren with study matorials which conform to the tandards of modern oducationsl thought?

What the requirements of a modern textbook in soventh-grade arithmotio are is a quastion whioh cannot be answered withont oareful examination of an extensive body of odnoational and paychologienl I1toraturo. As 18 show in Ohapter. III, the anowor to this question, as far as can bo dotormined, Io not always givon direotis in the I1terature but mast be dorived from bas10 philosoph1es and researches oovering a wide variety of r1elds that have contributed to the funcor high school moremont. Thilo a certain degree of contradiotion is found, the general agreoment as to spocifio requirements for the modern junior high school arithmotic 
toxtbook 1s remarbablo considering the diverse flolds from which these specifloations come. Careful examination reveals that mang of the soeming contradiotions ar1se from fallure of various riters to disouss comparable points or because they disouss the samo things with reforonos to various applications. in general, the analysis of the Iiterature presented in Chaptor III rarrants an establishing of dofinite standards wheh should bo mot before sohool mon purchaso arithmotio textbooks at this level and evon before publishers place the books on the market. Whilo it is not olalmod that tho mothod of analysis presented in this thesis is complete, or perfect, it is claimed to be a distinot improvemont over the hap-bazard mothods commonly employed in textbook analjais.

The 1mportanco of adequate textbook anelysis prior to adoption is omphasized by Jensen ${ }^{1}$ wo askod 172 Superintendents of schools: "Do you build a course of study and thon seloct a textbook, or do you selost a textbook and thon build your course of study?" Bighty-five peroont of these superintendents ropliod that thog built a course of study and thon selectod a textbook, wile the remainder replied that they selected the textbook and thon built the course of strdy.

ICabveII, H. I. and CampbeII, D. S., Curriculum Developmept. American Book Company, Naw Tork, 1935, Pp. 45-47. 
In v1ew of these practices it is ovident thet oity school systoms noed som definito procedures to follow in determining how adequatels var1ous textbooks moet the requirements of their courses of study and of modern odroational thought.

A solentifio attitude toward the study of a.1 sohool problems has brought about a change in mary of the teobniques formorly used in selecting textbooks. So far as sohool peoplo are ooncerned, a toxtbook should be a good oducational tool to be satisfactory. Onfortunatels, they have maxked diffioulty in determining oxactly wat constitutes a good oducational tool. A toxtbook that was satiofuotory a genoration ago mag bo totally unsuitable today due to obnged soolal and oconomic conditions. A text whose mochanical features placed it in the forerank in this rospect a fow years ago may not be usable today because of improromonts in manufacturing and terials, and bocauso of rocont researchos in the field. Ubviousis, a toxt that is ldeally adapted to ono locality or to ono lovel of ability mag bo very mach unsulted to anothor. In 1929 vecormick ${ }^{I}$ made a study which comparea the contents of eleven serenth-grade textbooks publishod since 1925 with ton publishod prien to 1923. The books

I coCarmick, clarenoe, The Teaching of General Mathomatice In the secondar sohoole of the united Steter. Toachors College, Columbia vaiversity, Contributions to Bdueation, Number 386, Chapter V, P. 61. 
from the two periods contuined about the same amount of stat1stioal material. In every other branch thore was a very noticeable difference. Plane arithmotic dropped from an average of about elghty percent in the eari1er group to about effty-nine percent in the later one. Intuitive goomotry increased from sixtoon to twonty-one percent.

In a more detailed study Daris ${ }^{1}$ presonts oridenoe obtained through an examination of ten series of three textbooks eaoh which were publishod within tho last fourteen years. She shows that each of the ten authors offered materials from arithmotic, geomotry, and algebra in the seventh grado. The following of lis. Davis' conclusions are notoworthy: (1) Much use is made of material for motivating all phases of the work; (2) A tondoney is noted to present work in a pogchologloal rathor than a $10 g 10 a 1$ manner; (3) Hochanical probloms are given muoh loss space than vorbal problems; (4) A tendency 18 present to develop practienl rather then Impraotical mathomatics; (5) Huch offort 1s dovotod to training the ohild for quantitative interpretation. The Iirst etep in the presont atady was to determine current practices in textbook seloction. These are presented in Chapter II. Here it 18 shom that textbooks are chosen, for the most part, because

IDavis, D. R., "A Comparative study of Textbooks in Jumior High School Hathematies. High School, Volime 8, Number 2, February, 1931, Pp. 103-114. 
of factors othor than value as teaching devices-prestige of the author or of the publiahing company, or both, ote.; that the acore card alone is an inadoquate tool for seleoting a textbook and should be supplomonted by painstaking analysis on the part of apeciallste in the field, preforably those who will use the text, providing thoir other qualifications are satisfactory.

The characteristics which the modern seventhgrade arithmetic textbook should possess, as outlined In ourrent oducational and psychological litorature, aro givon in Chapter III. Lack of unifleation and cohosion in the anaigsis of the I1terature is inevitable. A large number of individuals have written more or less direotiy about this problem; many of them have touchod the matter onls incidentally wh1le dealing with some aspect of a very different jor problem. From this, seemingly, disorderly array of 11terature (all that was available to the writer) come the desiderata of the modern seventh-grade arithmetic textbook as given in the trenty-aight headings of Chapter III. the next step in the study was to determine how adoquatels modern serenth-grade arithmotic toxtbooks mot the requiremonts of modern oducational thought. Preliminery analya1s was made of all the availablo seventh-grade arithmet1c textbooks published from 1026 
to 1935, Inolnsive, ton year span. In tho oplnion of the writer, those for 1934 and 1935 seom onough alike to bo considered as bolonging to the same period and so different from those publishod prior to 1934 that those from the earlier years could not reasonably be considered moderz. Sinoe the atudy was bogm in 1936 textbooks publishod later than 1935 wero not avaliable.

Careful analjses were made of the six soventh-grade arithmetic textbooks 11sted in the cumplative Index of Perlodic IAterature for the jears 1934 and 1935. While analyais of more boaks would have made the atudy more usetul as regards differentiation between texts, only six were avallable for these jears. The Inciusion of books from the tro-jear pericd was considered advisable in order to secure as large a sampling as seomod consiatent with modernity. The atudy of a greater number of books rould have involved a timo span which might have complieated and confused the 1ssue, since a long-time study would have introdused the factor of orolution, shown by McCormick, as osted above, to suoh an extent that the books analyzed would not be contemporary. It soemed further advisable to make an attoupt at analyzing only books which would be contemporary with the 11terature from which the mothods of analgsis were derived. For the most part 
texts are publishod from two to flve jears aftor coum pletion of the manuscripts, sometimes longer. Porlodic 11terature does not, generally spoaking, have a couparablo delay in publication. While analyzing IItoraturo and toxts from a strictis comparable poriod was 1mpossiblo in this study, the two types of literature are, for the most part, contemorery, when Iag of publication is allowod for.

these alx textbooks were examined, analyzed and rated as to whother they wore superior, average, or Inferion according to the twenty-elght oriteria set down in Chapter III. These analjses are given in Ohapter IV. The toachere making the analytical rating: were: Msses Mirlam Hoymann, Al100 Ba1ley, Bsthor Barth, Nary Corcoran, and the witer, all teachers with extensive experionce in seventh-grade arithmotic in the Ioulsville publ1c sohools.

Whother these teachers are qualifled to malko such eraluations way be questioned, of course, as it may be considered dobatable that angone 18 so qualifiod. These teachors are intimateis in contact with arithmotio Instruction at this lovel and have had recent ocntact with university courses in education, and have assisted with currioulum reconstruotion in the Loulstille schools.

Whother five juages are sufflelent to insure a requisite degree of accurrey of judgment 7121 depend 
upon how well their ratings agree one with anothor. Bxamination of the data given in Chapter IV shows a high degree of agreempnt - at least as consistent as those used by Terman and Cox in ostimating the intelilgence quotients of three humired geniuses. ${ }^{2}$ since, in the opinion of the judges, none of the six moderm seventh-grade arithmet10 textbooks adequately mots the requirements of moderm educational thought as lasd dow in Chapter III, specifle rocommondations are made regarding the usage of arithmotio textbooks at this level in the Loussville publio sohools. These are given in Chapter $V$, togethor with a sumary of the findings of the study.

${ }^{I_{C}}$ ox, C. C., ithe Early wontal yraits of rmpee Humdred Geniuses. cenetio studies of Genius, Volume II, stanford Iniversity Press, 1926. 
CHAPTIR II

HOW TEXXBOOKS ARE SELECTTED

I. The ralue of a book as a teaching derice has little to do rith its selection as a textbook.

Because those responsible for the selecticn of textbooks have not been equipped with tochniquos that would insure sdequate analysis, speclal argumonts have been used by publiabing companies to Influenoe their choloes. maxwell $I^{1}$.1sts the following as the most common and the most effective of these: (I) tho prestige of the author. It has been tekon for granted that an author wo has a reputation as a scholar in his Ilezd 1s equipped to prepere a textbook for onjlaren. Fabllaking companies have made molh uso of this axgrwont as ono of the basic considerations for the excellence of a text. (2) the prostige of the prablishor. rhis has beon used partioularis by largo companies and thes bave disparged the books of more recent comors in the 11031. (3) the genoral eppearanoe of the book. 1h1s has rocelved wane omphasis. (4) the ride nse of the book. Whis 1s one of the most persistont argumonts and In the opinion of the pablisher, author and purchaser, a good text 1s, quite generally, one that selis

Ilaswe 11, C. R., "Iho Use of Se ore Cards in Evaluating Iextbooks " mational society for the study of Edncatiop, thirtieth Yearbook, Part II Publio sohool 143-146. 
w011, rogardless of a.1 4180 . (5) The cost of the book. 1his, as an argumont, has mado a distinot appeal when rocommondations have been made to sohool boards. When publishing companios b1d againgt each other for adoptions, it naturalis appoars as a vital cons1deration.

II. A seore cand alome is imadeoute.

Somotimes soore cards are used for evaluating textbooks, but according to bwoklngham, I a score card alone does not inaure sclontifio mothods or results. solence calls for more than an instrumont. In the first plece, the instrumont must be gocd ono; socondly,

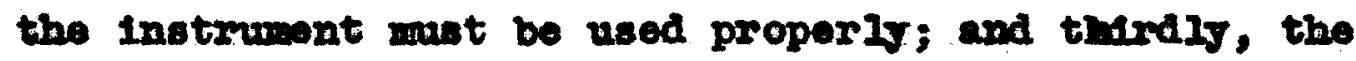
user of the Instrument mast have a selentific attitude. By solontific attitude is mont open-mindodnoss, froodom from projualce, willingness to consider all viewpoints, a wlIlingness to seek facts whorever they are to be foumd, and the drawing of only suoh conclusicas as aro varxanted by the data.

Onless suoh eriteria are set up, say Maxwell, the objectives of the school system may be lost sight of in the seloctica of textbooks.

It 1s not easy to make a good score card, and textbook oomittees soon disoover this. The basis for

I Buckingham, B. R., "lho solentific Development and Evaluating of "extbook", Department of superintendents Off101al Roport. Fobruary 25-barch 2, 1933, Pp. 169-166. 
weighting and oven for selecting the items is likels to be nolthor objective nor 1martial. the textbook comaltiee mast elther make 1ts own seore card or adopt one from some othor sorree.

A good aritbmotic scoro card contains such beadings as: Problen material, procosses in drill, diagnostic and romedial fortures, provisions for individual differonces, phosical foatures, and vocabulary and sontence stmecture. It 1 s generaliy agreed that this last foature deserves far more detalled attontion than it usualis gots. A fairly typical scare cand is given below. The Inadequacios of suoh a device takon alone are at onoe apparent:

$$
\text { IYPICAL SCURE CARD }{ }^{1}
$$

(Books that are superion, arerage, or inferior in regard to the Items given bolow axe rated as 1,2 , or 3 , respeotively)

I. Organizat1ca:

$$
\begin{aligned}
& \text { a. PIan of coumse } \\
& \text { b. Iog } 1 c \text { or dovelopment } \\
& \text { o. nnner of tying up, munising } \\
& \text { a. Conorete first, abstraot later }
\end{aligned}
$$

II. STYIE OF PRESEMTATIOM:

$$
\begin{aligned}
& \text { a. Clear, coborent, unified, conolso, } \\
& \text { adequate, appealing to both sexes } \\
& \text { b. Bffeotive presentation of vocabulary }
\end{aligned}
$$

III. ONDERIYING PSYCHOLUGY:

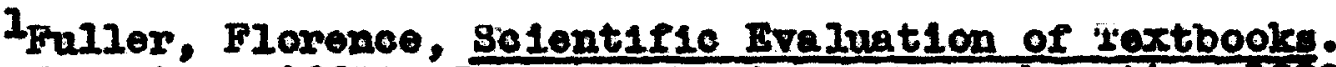
Houghton miffien company, Boston, 12ssaobusetts, 1928, P. 66 . 
a. Fram lnown to unimom

b. From almpio to complex

- One alffioulty at a timo

d. Offoring motivation

- Stimainting thinking

f. Stimalating initiative

g. Observing laws or recency and frequency

h. Ut1lizing that which has been developed

IV. AIDS:

$$
\begin{aligned}
& \text { a. Table of contents } \\
& \text { b. Indices } \\
& \text { o. Appondix, tables, oharts, supplementary } \\
& \text { eterial }
\end{aligned}
$$

V. PROVISION FOR ABILITY DIFTERIEMEES

VI. APPEAL TO INHEREST:

$$
\begin{aligned}
& \text { a. Plotures } \\
& \text { b. ritles, hoadings, otc. } \\
& \text { o. Simplieity } \\
& \text { d. Derioes--for fun, gamos, contests } \\
& \text { - Bxplanations as to userulnoss or matorial }
\end{aligned}
$$

\section{Practioes in large o1t1es:}

In Boston the methemat1es ooune1l adopts a 11st of textbooks, an on whioh the toaobor w use. In the junlor high sohool grades of Cleveland, different texts are adopted for uae with $X, Y, Z$ groups, roprosonting the bright, modium and sow pupils. In wost aystom, Lsal ${ }^{2}$ formd that a singlo textbook was adopted and that all teachers felt that they should use 1t.

In practically all sohools visited by Lddo, textbooks are selected through a committeo appointed for that purpose, each momber of which uses his om

1 Lade, Eawin S., "Instruotor in wathomatios", United states Departmont of the Interior, Office of Education, Monograph nwuber 23, 1938, number 17, Pp. 17, 18. 
mothods in arriving at a conclusion. A school orficial In one of these cities felt that publishors of toxtbooks affected too mach the oholoos made. Corteinit, the selection shoula be ande on the extent to which the books roprosent the 1doas of the staff relative to materiels and mothods. It is most unfortunate that the 1dees of most oomittoes are not bettor orystali1zed and more objectirels administered. who socere oard given above was devised to assist in sueh solections. It has been used in the Ios Angelos junior h1gh schoole, but with what awocess, we are mable to determine. IV. Hou pabliebore ceoume manuscripts:

In orter to learn how publishors socwe manscripts for taxtbooks, Jonsen asked this question: "What mothods do jou emplog as a priblishor in the socuring of manusoripts and of authors to writo manusoripts for textbooks?" ${ }^{2}$ iJpleal anowers were: "A great mangeripts aro offored to us. wang oom to us through advisong oditors. Oup om caltors are in oridenoe at oducational gathorings and are orten oonsultod by teachors with rogard to books in process." "Our oditors and ow fleld ropresentatives try to keop Informod of manuseripts in preparation and of persons quallfied to do spocial work of this soxt. Wo find

Imanel1, C. R., "rho Use of So ore Cards in Evaluating rextbooks." Wational Soeloty for the study of Iducetion. Mhirtioth Yearbook, Part II, Publio Sohool Pubilshing Company, Blocinington, Iilino1s, 1931, P. 80. 
authors by porsonal contact. Om oditor-in-ohlef makes It his business to investigate prespective authors personally. Sometimes the author brings his matorial unsoliolted to the publishor and if it is found to be ouffiolontis moritorious to justify preliminary oxaminat1on, the material is considered in the light of mooting present-day domands as roflocted in the roports of educational comelttoos representing in a Imgo dogree tho Ideas of the tims. Iho all 1mportant thing is, IIrst, Whothor thore 1s a surfielont dowand for suoh a book to justify the expense of publication; and socond, tho quality and organization of the material.

"In nearly every case wo decide on the subject, then seek the author. We seldom accept readymado maseripts."

Prablishers are always on the alort to find prospeotive authors. Somo publishers have a spoclal department to discoror authors and matorials for publioation. In author unst have rooognised atanding in h1s 1101d. Subjoot matter mast oonform to the oduoat1onal demand. Ihe oduastor wo is responsible for the swooess of the sohools mast ay that tools are noodod. The publishor attempts to prodince the typo book ho thinks tho eduoator w11l want.

Most of the present authors are 00110ge professors who are experts in the varlous sohool subjoots. These mon often are assisted by public sohool 
administrators and teachers. ro quote Rugg: "sinco 1895 textbook companies with an ofe to sales have tonded more to form partnerships of professors and publ1e school workers--suporintendents, pripcipals, or teachers. Fow sohool books get wide adoption that are not propared by suoh a partnorship of aubject mattor, authority, and practioal sohool administration."

Publishing compenies mat antlelpate and measure the need for a ner textbook before butlding one and placing it on the market. Criteria used by the publiahor to determine the noed for a now textbook are ahout as follows: 2 (1) Constant watchrulness of eduoationel movemonts as rofleoted in addresses and mitings. (2) Tho offorts by fleld represontatives to dotoot oducational tondencles and a roal domand for textbooles. (3) tho lenowledge that there is a dissatisfaotion with oxisting texts. (4) Reports of comitteos on ourrioula, new ocurses of atudy, artioles in educationel perlodicals, discussions in oducational moetings, and the reports of F10Id mon.

V. Sxmaxy

tho value of a book as a terohing dorloo has

\footnotetext{
IRugg, Harold,, "Currioulum-makeng via Mational Committoes." Mational soclety for the study of Education, rwonty-sixth Yearbook, Pubile School Publishing Company, BIocmington, Ilino1s, 1927, P. 65.

ZJonsen, Frank, "rhe selection of nuseripts by Publiahers." wational soc1ety for the study of Eduoat10n, ihirtieth Yearbook. Publ10 Sohool Publishing Company, Bloomington, Illino1s, 1931, Pp. 80-91.
} 
Iittlo to do with its selootion as a textbook. rextbooks are ohosen subjectiveIs and usualiy without adoquate oraluation. Eron whore a score oard 1s omploged, 1t furishos, generally, a superricial judgment. Where teachers are lert to choose their ons texts, as is common in many sohool systems, or whore they have several acooptable ones to ohoose from, they still are 11kely to make inadequate analyses of the books ocnsidered. Wholp choloes are influencod very mon by publishors, presumably because the teacher has no adequate mothod of textbook analysis.

It is agreod among educators that effective textbooks cannot be sooured unless the publishor and the sohoolman work together with the interests of the ohild in mind. In this joint offort, tho ovaluating of textbooks assumes major importance and the derelopment of the text of the future will be the task of both author and publisher. Onfortumetoly, the moders text, speaking generally, is primarily the ooncern of the publishor who selocts authors, manusoripts, and Ideas out of whioh textbooks arise, and no satisfactory oriterla are applied to the text as a teaching tool, elthor before or after publieation. 


\author{
CHAPTER III \\ STAMDARDS FUR THE MUDERM SEVENHE-GRADE \\ ARITHWEY LC 'IRXIBUOK
}

An analysis of tho ourrent oducational and peychologioal IItorature, as outlined in unapter III, warrents an ostablishing of definite standarda wich should be mot before educators select arithmit o textbooks at the seventh grade level. whose standarda are as follows:

I. ithe modern seventh-grado arithmet18 textbook shoula haxe a soond philosophical backeroumd relative to the suct 1 ons of arithmetic.

In deciding what to put into a textboor, authors shovla be gulded primerily by educational theory as woll as by considerations of practioe and soolal utility. since it is the alm of aduotion to f1t the chila for 11fe, 1. $0 .$, for growth that drams upon the present envireament, the prosent oapaolties, and the present interests of the obild, edusati on and the textbook mast be flexiblo. line ohila mast bo trained to make his om adjustmonts and to moet unforeseon olroumstances.

Arlthmotio should malro a vital contribution

Ischorilng, K., "ihe High sohool reecher in the waking", the High sohool ieacher and the rextbook, Ldraxds bros. Tru Trbar, Mokigen, 1931, P. 1 . 
to the intelligent consideration of rapious aspects of businoss, consumption, production, gevermmont, and scolal relationships which lend themselves to quantitative study and analya1s. the real moaning and sifnif1eance of profit and 108, the responsibilities and diffleulties of the hom and business ostablianments are part of the r1ejd of arithotis. Ar1thmotio offors an opportinity for the Indiridual to becoms moxe intell1gont in his selection of rood, elothing and sholter: that is a more Intelligent ocasumer.

Cortain topies in arithmetio may be well used as a wans of showlng how complex international prob10xw bave been settled by common agreemont. The metw10 ayster ropresents an Intereating 12lustration of an attempt to solve by common asoeptance of a almple deolmal gystom the rexing problems are to a lack of miformit in measwement mits among difrerent countries. qextbooks have w1der use now than over before. Axithmotio is taught primarily as presented in these rexts. If the onsia is to dovelop a basis for expressing h1s ooncepti quantitatively and in orierly manner, ho mast learn to express relationahips clearit. If ho 18 to Ieam these things, he mut leam the tecmiques that have been invented for stating these relationships, atoh as ratio, average, modian, por oent, mode, and other suah deviees. such terms oocum in books othor 
than texts, In nowspapers, and magazines. To read Intelifgentiv he mas have a tmie appresiation of tholr Iunetions. Inls oan bo acoomplishod only throngh the axithmotio textbook hose writex has beon guided by soupd educational and poyohological prinolples. ithe modern arlthmetio textbook must reoegnise that hablts are orsontial for ooonong of action and anst aro provielea for their establiahnont. itho mumber faots should be reduced to a hahlt bas1s. But confronted by infandliar situations hab1ts no losger neet the noed and number facts beocme insurfiosent. ihe edw ated porm son is a think1ng porson, and a fundamontal problom of the molern covrse in arithmotio is to teach ohilaren to think. infs eannot be done miess the chilaren are placed in alvuetlans requiring thought. In the soolal onvironment these stuations are ealied problum, and arithmtio offers experienees wieh 11kew1se are called problems .

the Importance of a proper philosophical appreach to the toaching of arithmotio 18 indieated by Sohorling and Bagley tho ear: "In ow soosondary sohools the most important factor next to the reacher is the cextbook. For most teachers tho eurrieulum and the rextbook aro identioal. ino inadeguatoly trained teasher and, In most cases, the beginning teacher need to roliow a textbook in gystomatio fashion. It is a 
very poor textbook indeed that is not better than no textbook." 1 "whatever the orils of the textbook sjatem way be, it 1s fairly elear that it is about the only force in Amerioan oduoation that reflects a systematio and oxderly procedure." 2

While the exact nature of the seventh-grade texbbook in arthmotio is not speo1rically outilnod in modern courses of study, there is absolute agreoment that careful consideration should be given to basio educational philosophles. Aocording to the lourse of study of the state of wor $x$ ork, 3 mathomatles at the gunior high sohool level should depend upon a broed ph1losoph of education rather than following the momontary Interests of ohildhood or unduly strossing alleged lifo noeds dicoovered by inventories of adult 1iterature and rooktional practioes."

A falriy comprehonalve 1dea of the nature of this general oduontional phllosophy 18 giten in the Forenond of the Indianapolis Course of Study for $19348^{4}$

Ischorling, R., "Iho High School reacher in the valeing. the High School Hesobor and the Hextbook, Bdrards Bros., Ann Arbor, IfohIgan, 1931, P. 1 .

¿bagloy, Wm. C., "iho rextbook in Aworican Rducation". School and soolety, Volume XXXIII, Vareh 14, 1931, P. 358

Joniversity of the state of Mer york, A STIlabus in Junior High Sohool lathomatios, Albeny, How York, 1938, P.2.

Indianapolis Publio schools: Course of studr in latheaties for the Jinior High sohool Difialen of the Seocendary sohools, crades 7-8-9. Board of school commiseloners, Indianapolis, Inilana, 1934. 
"tho general ain of the course (Junior High School vathomatios) is to provide oxperiences and suge gest activities wich will help the pupil,

1. 'to develop speod and accuracy in the frumdamental operations through thoir more diffieult applieations; to dorelop an understanding of thoir use through a wider relation to how, sohool, commmity, and business life.

2. ro gain such a lonowlodge of geomotric form and dimonsion as is userul in the ordinary activ1ties of I1fe.

3. Ho acquire the algebraic lonomlodge which is userul in simple monouration and comenon business practices and to have an opportunity to mater the fumdamontals essential for advanoed work.

4. ro disoover mathomationl ability and partionlar Interests and capacities so that Intelligent oholoe of sonior high sohool subjects may be made. 5. Ho gain some approciation of the value of mathomat1os in every-day life, in related flolds or knowledge, and in adranced work in the subject. 6. Yo develop a clear notion of the relationship botweon the rarious fiolds of mathematics and the Inter-dependence of the various thomatioal operations. 
7. To develop: greater powor in problem solving, responsibility and nood for accuracy, satisfaction in thorough and procise work, and ab111t to ostimato appreximate results."

In exphasiring that constitutes an adequato oduoational phllosophy the Mer York Course of Study eays $2^{1}$

1. No Idea should be emphasized which does not have inhorent whematical or practioal value.

2. Mow Ideas would not be introduced unless their ectual use w11l be rolatively 1mmodiato.

3. Her Ideas ahould not be introduced until tho ohild has the proper background for thom.

4. Onls one topie ahould be studied intonsively at one time.

5. 111 processes should be given onough attention that they will be loamed. Certaln onos should be made automatic.

6. Reviers and summarios mast be provided.

7. Individual differences mast be provided for, ospocially as rooational aids.

8. the struly mat not be compliested.

9. Intultive geomotry should have more attention than is customary.

Toniversity of the state of Mor York, A rentative STllabus in Junion High School in thematics. who University of the state of Net York Pross, Llban, 1928. 
10. Algebre should be reoognized."

Clearly then, the task of the author of a modern seventh-grade arithmetic textbook is a diffieult ono as respects philosophy. Ho mast boon wat philosophy 18. Ho mat apply it in such annor that it w111 runction with the pup1I through the textbook and through the taecher. Ho must at the same timo conform to current usage through careful analjais of courses of study and coupeting textbooks. He must consider the oriterion of soeial utility with reforenos to the noeds of both ohlidron and adults. One of his major problems will be to consider the functions of arithmot10 othor than the oomputational. He mast consider not only what numbers pooplo do use, but also the numbers that they need to use and for what purposes other than for mere computation.

I1. the moderp serenth-grede erithmotio textbook should provide a cound srater of oharacter and eftirenahip training. 1

Few flelds offer more definite opportuntties for specific training in oharacter and oftizenship then does themetios. All modern educational philosophies emphesize the orying need for such training; many of the writings relative to juntor high school mathomatics

Indianapol1s Public sohools: Coumse of study in athomatles for the Junior High school Division of the Secondary Schools Grades 7-8-9. Board of School Comprasioners, Indianapo11s, Indiana, 1934. 
montion the posalbilitios offered for such training in this fleld. Unfortunately, spocifio directions as to how this training is to be givon are usually laoking. Perhaps the most specific thought on th1s type of training through funior high school mathematios is given in the Indienapolis Course of study. I'hey say ${ }^{1}$ "While the purpose of teaching themes is not essentially character and eitizenship training, man stuations arise in connection with this work which offor distinot opportumities for the development of desirable oharacter and civic traits. since there Is moh individual activity, for other subjects afford as much practice in developmont of habits of Industry and perseverance, and reliance upon one's own efforts. llathemetics problems challenge the pupil's resourceruiness and originality, and achlevement based on falthful honest effort brings a foeling of satisfactica. which stimulates furthor offort. reachers should plan the elassroom procedures so carerully that temptations for dishonesty and carelessness on the part of pup1ls are removed as far as posa1blo. Every pup1l's work should be carefully cheoked before oredit is given in order that only careful, accurate, honest effort is properly rewardod. whe teaching of mothematics should

\footnotetext{
Indianapol 1s Public sohools: Course of Situdy in thematies for the Junior High Sohool DIVI010n of the secondary sohools. Grades 7-8-9. Board of school Comists s10nors, Indianapolis, Indiana, 1934.
} 
ostabliah an appreciation of the necessity of exactness, a love of accuracy, and an understanding of the contribution of mathomies to our social iffe in sclence and invention. Sinco some of the units in mathemat10s-benking, insurance, taxes, household pract10es-o relate very definitely to social activitios, the pupils should gain a deoper appreciation of the dutles of an upright citizen in the community, eapecielly in rolation to IInanolal obligations."

III. Whe yodern sevonth-grade ar Ithmetic textboole ghoula have a roeabulary of suitable difflculty for seventhgrade ehtraren. 1

It goes without saying that probloms unst bo expreased in the vocabulary which oblidren oan understand. wew terms should be introdueed when needed, and the sentences must bo simple enough that the pupil can read and understand thom. warweil points out that textbooks have boen fornd practically worthless oring to the charaoter of the vocabulary used. ihls 18 amply supported by the findings of Patty.

For wny years it has been reoognized that the diffloulty of the rocabulary in which a book is

\footnotetext{
lpatty, W. W., "Ihe rextbook and Its Vocabulary", Journa 1 of kucational Research, Vol ume 34, number 24, Jumo, 1931, P. 145.

8patty, W. W., "ihe rextbook and Its Vocabulary", vourmal of Eancetional Research, Volume 34, vumber 24, June, 1931, P. 145.
} 
witton 11mits the group with wioh it oan be used and plays a large part in determining its usefulness as a text. Professor rhorndike of Columbia University was one of the first, if not the first, to make practical applicetion of this finding. In 1921 he pub11ahed tho reacher's word Book, a compliation of tho 10,000 most frequentis used words in the ungliah 1anguage. wh110 Professor ihorndike did not olatm that the frequency with wioh a rord 18 used is an exact measure of its diffleulty--the axtent to wion it 18 understood by children of a given age--1t has been found that the rolationship between frequency of usage and maerstanding of vocabulary terms is so oloae that those who write textbooks for chilaren mist ocnsider whether or not those for whom the writings are intended w111 be roasonabls well acquainted with the temms used. It should be the business of the authos to know the tecmnieal and 11 terary words with wich he is loading his text as woll as to know the facts of subjeet matter.

So far, we have no adequate masare of oxactly what percent of the vords a child moets in a textbook he should be familiar with or understand. If he knows all of them there will be no grouth in

Thorndike, K. L., The 'Heacher's word Book, 'Heachera' college, Colwbia iniversity, How Yoxt G1ty, 1921. 
langruge mastery; if he lmows too for of them ho w11l become discouraged and will have to spend an woreaconable amount of time with the dictionary. Jensen and sohrodt, ${ }^{1}$ working with sixthgrade chllaren, found some relation between the frequenoy or usage or rords in compositions and how mach was lenrned from thom in a limited poriod of timo. rhey found, however, that factors other than frequeney of usage had more to do with learning where the ditrerenoes in rrequency of usage were no greater than are oxdinarily found in textbooks intended for the same grade. whoy say: "... what a child loarns from a fire-untaute atuaty period 18 not wholly dopendent upon the above named factors-momprehension, recabulary difficulty, phrase and sontence length. In our opinion, style of presentation, key sentences, otc., are vital factors. It seoms to us that too much 'story' way actually detract from learning and that study materials my be too 'entertaining' to be good teaching devioes whero time is Iimited." they did rina, howerer, in a proliminary (impubl1shod) study and in the publishod study reported, that in the textbooks compared and the study sheets of graded difficulty from which the chlidren learned most rapidiy contained, on the whole,

IJenaen, M. B. and schrodt, M., "Language Difficulty and Lorming: the Kolative sffectiveness of series of Study sheets of Gradod virficulty as leaching Devices with Children in the 6A Grade." Ir. Genetic Yerohologr, Volume XIIX, wumber 2, December, 1936, P. 451 . 
much more frequently used words than did those from which the oklidren learnod more slowly. If wo mag accopt thoir findings, judgmonts of empotent "rators" mast be usod to supplomont vocabulary counts, moasures of sentence structure, otc. In arriving at proper analyses of textbook difficulty.

4 atudy tade by Kramer ${ }^{1}$ showed that the unfamiliarity of term made a difference in the accomplismment of pupils in solving verbal problems. Kramer furthor shored that the group which solved problems conteining only famfliar rocabulary gained 6.5 per cent more than the group which solved problemo containing unfamiliar torminologs. brueckener fornd that the correlation botween computational ability and understanding of quantitative relationships was .417. He concluded, "... a pupil's xating on a computational test is not a reliabje index of his ability as moasured by the rocabulary or quantitative relationship text." He foumd a high correlation between problem solving ability and rocabulary. Grossniokle 3 made atudy which is concermod

IKramer, G. A., the Bffect of Certain ractors in the Verbel Arl thmotic Problems upon Chilaren's success in Their Solution. "the John Hopkins Un1versity Press, Baltimore, Varyland, 1933, Pp. 58-61.

2Bruecloner, I. J., "Diagnosis in Artthmotio". national society for the study of Education, inlrts= fourth Yearbook. Public School Publishing Company, Bloomington, Ilino1s, 1935, P. 273.

3arossnicklo, F. F., "Concopts in social Arithmetic for the Elghth Grade Ievel." Jr. Educational Research, Volume XXX, Number 3, Narch, 1937, Pp. 475-488. 
with the informational phase of arithmetic as 1t relates to an understanding of certain coneepts found in the soolal usages of business arithmotic. The purpose of the study was to find the degree of aocoupliabmont attainod in mastery of cortain concepts by the pupils when they had completed the eighth grade.

A l1at of s1xty-oight thematiegl conoopts In the business usages of arithmotic was found by analjzing thirteon different textbook serles for tho seventh and olghth grades. 'these conoepts wore grouped as follows: banking, stocks and bonds, taxation, Insurance, morehandising, bullaing and loan assoclations, and installment buiging. the atudy shored that the level of attainmont in matery of conoepts in most of the schools was about the same. Yot in only one of the sohools was the arexage attainment more than two-thirds of the total possible. If the fudgment of the textbook writers is a valid eriterion for the worth of conoepts, then a class whioh has a working knowledge of only trom thirds of the mathomtical term from an assigned 11st, has not made a reoard of achlevemont that merlts suoh praise. However, the major part of the oritielsm for the low level of achlevemont of most olasses should be placed upon the textbooks since the concopts which the 
- Iasser moot in daily arithmotic are dotermined by the text it uses.

Bureh ${ }^{2}$ found about as mach difference in diffieulty betweon the ilterature books ondinarily used in one grade of the funtor or sentor hlgh achool 28 there was botween the average reading ability of the varions grades. In other words, some of tho books were mach easier to understand than were othors used at the same grade 10vel. Sho coneluded that tho I1terature Intiended for the twolfth grade could be used as satisfactorily with students of the ninth grade as man of the books they were using. The fault, undoubtedis, doos not 110 with the children, with the sohools, or with the teachers, but with the books whioh, from the standpoint of diffioulty, are not adapted to the ohildren with whom they are used.

IV. Sentenoes and paragraphs should be brief, simple, and unifled in the modern seventh-grade arithmetio toxtboot. 2

Jensen and Solmodt ${ }^{2}$ rewrote a section about Arabia from Gibbon's History of the Deeline and Fall of the Roman Finire to form a "series of five selections

$1_{\text {Burch, M. C., "Determination of a Content of the Course }}$ in Literature of a suitable Difficulty for Junior and Sonlor High Sohool students." Genet10 Psrcholocr lonographs, Volume IV, Numbers 2, 3, Fobruary and Zarch, 1928.

ZJenser, X. B. and schrodt, M., "Language Difficulty and Ioarning." Jir. of Genet10 Psrohologr, Volume XIIX, number 2, December, 1936, Pp. 451-467. 
(inoluding the original), uniform in content, but difforing markedy in difficulty". In the opinion of thirteon experlenced teachers these selections wore of diffioultios sulable for the 11.6, 9.2, 7.5, 5.5 and 3.7 grades. The average number of words per sontence was: $27.1,23.4,11.9,7.9$, and 10.4. tho mean longths of phrases were: $12.1,10.3,9.9,6.9$ and 8.6. The five selections were given to five carefully equated groups of sixth grade ohlidren to study for ton minutes after which thoy were all given the camo examination to find out how maoh they had Iearned. whose that studied the essiest selection soored almost twice as high on the test as did those who studied tho hardest seloction. the mean scores for the five groups on a teat containing IIfty-one 1tems were 15.8, 17.0, 20.5, 25.2, and 30.4. They found that about two grades difforence in suitability, as juaged by tholr thirteen "rators", produced a significant difforence In the amount that the children learned in a tonminute study period. While it is not elaimed that there is a direct relationshlp between the length of sentences and phrases and the coherence of the paragraph and how woll a chlld loarns from what ho studies, it is orident that these three factors should have vital consideration by the makers and purchasers of textbooks. An examination of current textbooks in almost 
ang rleld shows that the rocabulary has been greatly simplifled, many technical detalls have been omitted, and tho ontire presentation has beon made moro - lementary. There is still mach room for improvement, however.

V. The moderm seventh-srade ar1thmotle textbook should define new terms in context as ther are introduced. ${ }^{1}$

While little 18 made of this in most of the oducational literature, it is mentioned occasionally. Wherever toachers get together to discuss textbooks there is a general disappointment relative to the student's inability to use the dictionary well and, frequently, as regards the necessity for such a task. The introduction of new terms gradually and their dofining as they are introduced would save the student's time and free him from the discouragement of meeting mang terms with which ho is unfamiliar.

VI. the modera seventh-grade arithmet10 textbook should provice proper motivation through data related to the ohild's experience.

A real task of the author of an ar1thmotio

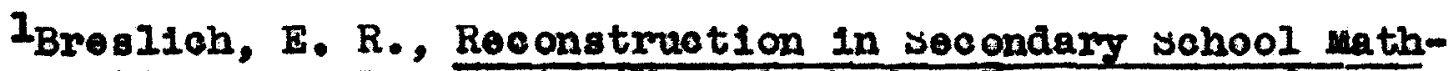
amat10s, Ph. D. 'thosis (Unpublishod), University of Chlcago, 1926.

2Buckingham, B. R., "The social Value of Arlthmetic". wational society for the study of Eduation, iwentyninth Yearbook, Public school Publishing Company, Bloomington, Iilino1s, Part II, 1930, Pp. 95-96. 
textbook is the utilization of the possibilitios of normal activities that give the pupil practice in a normal way, and to apply number as $1 t$ is applied in 11fo. Ihis procedure is made imperative by modern oduoational thought whioh says that the textbook mast bo Interesting to the ohlld. ro them, interest means effort, and a fundamental prinoiplo of intorest is understanding; henoe the great effort mast be made to arew problems from the experiences of onlld $11 f 0$. Bonthack ${ }^{1}$ and Buckinghan ${ }^{2}$ agree that utility is a major coneern of any textbook. It mast have moaning in the life of the enild and it mast give the child training for useful 11ving. Ihis, they fool, can be accomplished only by moans of materlals sulted to the interests, needs, and capacities of the child. Probloms mast be derived from natural altuations arising in the school, the home, and the commity, and they must be applicable to moderm business. this 1mplies the ellmination of the following traditionel materials from the textbook: (1) least common maltiple (2) greatest comon denominator (3) complex and compound fraotions (4) long confusing problems in oomon fractions (5) Apothocaries weight

I Bonthack, Bmil. "Standards for the selection of Arithmet10 Textbooks." Educational Research Record, University of Nobraska, Fobruary, 1929, Pp. 85-90.

2Buckingham, B. R., "The social Value of Arithmotic." national societs for the study of Education, rentyninth Yearbook, Public Sohool Publishing Company, BI00mington, IIIIn01s, Part II, 1930. 
(6) Troy weight (7) tables of foreign money, oases of percentage, oube root, and tables for surveyors and of compound annual interest.

Benthack further states that a good textbook should Include: (I) fundamental prooseses in arithmotlo--integers, common fractions and decimal fract1ons, denominate numbers, addition, and ono-place reduction (2) tables of length, surface, cuble, liquld and dry masures, aroirdupois, and Onited States money (3) the use of allquot parts, simple percentage with 8 implo interest and bank discount (4) monsuration-perimeter, surface, content of comon plane and solid figures (5) square root (6) businesa practices (7) taxes and public expenditures (8) the keeping of almple aocounts.

Burch $^{2}$ is in full agreement with this but goos oven further and says that how muoh a chlld loarns depends to a tremendous extent upon the amount of enjoymont ho reselves through doing the work prescribed. Onless the work gives pleasure, she sajs, there can be Iittio hope of Influeneing the ohild permanently. Sohang ${ }^{2}$ says that the distinotion between vorbal problems and real lifo problomg is significant.

HBurah, M. C., "Determination of a Content of the Course in Lterature of a Suitable Diffloulty for Jumior and Sentor High School Students." Genot10 Psrchologr Honographs. Volume IV, Numbers 2 and 3, Lugust-Soptember 1928.

Isohaar, W. L., Mathematics for Jumior High sohool Teachers - Johnson Prolishing Compang, NeT York, 1931, Yp. $217,420$. 
Fundamentaliy, the 11fe problem is the actual aituation 1tself, while the rerbal problem is only a description of that situation by means of language. This is a source of confusion and difficulty for the pupil. It is quite concelvable that a pupil who is able to cope auecessfuliy with problem situations of a certain difficulty in real Iffe maj bo a dismal fallure when 1t comes to solving verbal problems.

It 1 w we11 know that there are two types of arithmotic, namely, Informational and computational. Judd, Buckingham, and Butler' have shom the desirab111ty for greater exphasis on the informational type. that 1s, those aspects of arithmetic dealing with 11 fo situations.

VII. Explanations in the modern seventh-grade arithmetio textbook should be addressed to the pupil rather than to the teacher. 2

It is an all too comon practice for explanations to be given in language understandable only to the teacher. If the purposes of progresalve educat1onel thought are to be attained, the pupil must realize that the leaming of the subject matter

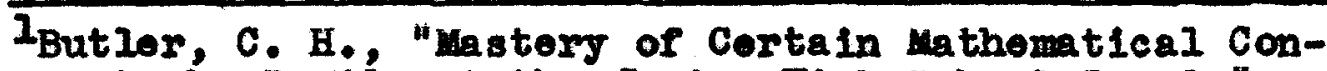
cepts by Puplis at the Junior High School Ievel." The Mathermatios Heacher, Volume XXV, Number 3, varch, 108E, $\mathrm{Pp}$. 117-172.

2Bresileh, F. R., Reconstmotion in secondary sohoo 2 Hathematics. Ph. D. 'thesis (Unpubilshed) University of Chicago, 1986. 
presonted is his problem rathor than the task of the toachar to toach him. In almost all modern educat1onal literature there is emphasis upon the necessity of making the child aware of his responsibility in the loarning situation. If this is to be accomplianca the modern textbook mast talk to him rather than about him or to the teacher.

VIII. the modern seventh-grade arithmotic textbook ahould provide 1lingtrations that visualize life situations for the child. ${ }^{2}$

Wh1lo the field of visual education is relatively now and fow dofinite data are available, most modern oducational ilterature emphasizes tho importance of adequate 1llustration. In arithmetic this should be done through oharts, graphs, diagrams, tc. of actual situations and data. The Importance of such procedures are implied through most of the mitings reviered in the present tudy, though specifie statementa are seldom given.

IX. whe modern seventh-grado arithmotic toxtbook gould frevide gemen and conteats to break the monotony. That muoh of the work of arithmotic may

I Breslich, E. R., Reconstruction in secondary sohool Mathematios, Ph. D. Thes1s (Unpubilshod) University of Chicago, 1926.

2West, R. I., Groone, C. W., and Bromell, W. A., "Ihe Arithmotic Curriculum", National society for the study of Bducation, ireatr-ninth Yoarbook, Public school Publishing Compang, Bloomington, IIIino1s, Part II, 1930, Pp. 95-96. 
read117 become tiresom is emphasized repeatediy throughout the I1terature. Ih1s is partioularly trus with the phases which should be habituated as w11l bo show under the disoussion on drills. Since modern educational philosophy emphasizes the advisability of utllising the chlld's natural tendenc1os, ono of whioh Ie to plaj in compotitive situations, it is oblious that provision should be made for such activitios in the modern arithmotic elass.

X. The modern seventh-grade arithmet10 textbook should provide adequate opportunite for practice in golving problems. 1

Verbel problems form the most sigrificant part of arithmot10. In solving problems the pupil gets the benofits of abstract examplos plus training in thinking through problems as he will moet thom in lifo experionces outside of school.

locording to "rhorndike," "good" problems w11l have the following dosirable qualitios: (1) the situations dealt with will bo such as are likely to ocur in real life, (2) the situations will be dealt with in a manner as nearly as possiblo analogous to that in wich they are dealt with in life, (3) the siturtion presented will be approximately the amo

Ischaaf, W. L., Mathematics for Junior High sohool Hegohors, Johnson Publishing Company, Nor York, 1931, P. 418-482. 
diffioulty as a sinilar life situation, and (4) the problem will be accompaniod by substantially the same degreo of motivation and interest as accompanies it In real 11fe. Furthormore, two other aspects must be kopt in mind: the aim of the problem, and the wording of the problem. The ohler aims of the problem are to cultivate the habit of looking for quantitative relationships, the ability to apply those relationships to 11fo situations, and the ability to arrive at proper solutions.

XI. Whe moderm seronth-grade arlthmetio toxtbool should Give adoquate attontion to the mathomatics or thrift and investment for overyiar uso--banking, interest, sarings, discount, budgets, etc. ${ }^{2}$

Whe Importance of this characteriatio of the modern seventh-grade arithmetic textbook is omphasized by nearly all witers in the fleld, almost irrespective of what they are writing about. It 1s listod, as previousis stated, by the Indianapolis Course of Study 28 one of the chlef objectives of eltironship training. All the discussions of arithmotic in relation to 11 fo stuations stress those important phoses of modern arithmot1c. W1thout question, the adapting of arithmetic subject tior is an important task of the modern

1schaaf, W. I., "Mathematieg for Junior High Schoel teachers". Johnson Publithing Company, New York, 1931, Pp. 125-130. 
textbook author.

XII. the modern seventh-grade arithmetic textbook should provide ooncrete problems such as those which require actual masurements to be made, estimates siven, etc. '

While the making of arithmetic concrete in the Iife experiences of the child by aotual moasurewonts and other performances is emphasized in the Iiterature, references as to how it is to be accomplishod are almost es vague as are the attempts or textbook authors to accomplish 1t. what it should be done 1s a tter of common agreement. As to just how 1t $1 \mathrm{~s}$ to be accomplishod and how mach time might be devoted to it is st11l a matter of subjeotive judgment.

XIII. the modern seventh-grade ar 1thmet 10 textbook should Instruct the pup11 for imodiate and future use of graphs and formulas, onable him to interprot thom intel11gently in his reading of nerspapers, mgazines, and other current literature."

Ihis is a generally accepted requirement of the modern ar1thmotio text. 111 oourses of study provide for sneh goels though the exact nature of the Instruction is left protty much to the teacher.

Ischasf, W. L., "Mathematios for Junior High school Teachorg", Johns on Publishing Company, Now York, 1931, Pp. 125-130.

2 Betz, William, "Mathematics in Modern Education", Nat1onal Counc1l of reachers of thematics, Eleventh Yearbook, Bureau of Publications, 'Heachors' College, Columb1a University, New York, 1936, Pp. 106-121. 
Bducational writers mention suoh objectives as important at this lovel of instruction in aritmotic. Wontion, as a mule, is incidental, however, rather than definite.

XIV. Whe modem arithmetio textbook for the seventh-grade provide a sufficlent number of roasoning problems Involving life situations. ${ }^{2}$

to be of most value, problems should involve those things which make up the child's dally interests and activities. Writers in the field are emphatic in that thore should be a large number of such problems as weII as that they should center about life situat1ons as shown above.

XV. whe modern seventh-grade ar1 thmotic textbook should have onough drilis to iron out the difficulties and make the correct methods mechanicol. 2

How much drill is nocossary for these purposes is not given in the literature. Until experimental investigations indicate the approximate amounts of drsll neoded, the judgments of expersenced teachers must be relied on in declaing if the drill provisions are adequate.

XVI. whe modern seventh-grade arithmotic textbook should

IBotz, william, "Mathematios in nodern Education", wationel Council of reachers of Mathematies, Eleventh yearbook, Bureau or Publleations, reachers ' college Colrmbia University, wow York, 1936, Pp. 106-121. "Brueckner, L. J., "ihe Critique of the Yearbook", National soclety for the study of Education, iwentyninth Yearbook, Public school Publishing company, Bloomington, Ililno1s, 1930, Pp. 687-692. 
have drilis distributed in diminishing amounts and at more freanent intervale.

As the child progresses through the course, or tmough the unit, in case the mit plan is followed, fower oxamples should be included in the dr111s and the drills should occur at more frequent

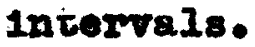

XVII. who amount or drill provided in the modern serenthgrade arithmetic should be proportionate to dsefy1 cultr.

more drill space should be allotted to those examples which involve a frequent difficulty rathor than those of the same type but of lesser diffieulty. For examplo, 604/2 1o much more diffieult than 624/2, because of the zero in the number. It should, of course, recelve more drill.

XVIII. Ihe modern seventh-grade arithmetic textbook should have "mixed" rather than "18010ted" drills."

Lase ${ }^{2}$ foumd from a twenty-six weok experiment 1n 1solated versus mixed drill that all pupils profited from drills, but that those using mixed drills showed twenty-threo percent greater gain than did those wing

I brueckner, Le J., "Ihe critique of the Yearbook", watlonal soclety for the study of Education, wentyninth Yearbook, Public school Publishing Company, Bloomington, Iilino1s, 1930, Pp. 687-692.

Zkepp, A. C., "Mixed Versus Isolated Lr1ll urganixation", Mational society for the study of bducation, pienty-ninth yoarbook, Part II, Public school publishing Company, Blocmington, Illinols, 1930, P. 535. 
1s0lated drills. they also learned to work more accurately and more rapldiy and tholr teachers roported that they sustained interest at a higher lovel or eff1cienoy than did those using 1solated ar111s.

Aoconding to Knight ${ }^{1}$ thore are two maj or purposes of arill: (1) arill to build a skill and (2) dr111 to maintain sk111. Shoer ari11 work, o1ther to leam or to maintaln imowledge, has 11 ttle gocial value in itself, though the solution of the problem requires acourate computation.

As early as 1910, Dower ${ }^{2}$ stated that dri11 material 18 worthwile only if children understand what tivg 1earn.

schorling and Hdmonson ${ }^{3}$ point out that the more desirable of the newer textbooks differ from those of a generation ago in that they include certain features which rest partzy on evidenee secured through 1nvest1gation. Among these features are: (1) A program of ari11 construeted according to specifications basod on experimonts in learning; (2) Hrovisions designed to moet

IKnight, B. F., "Somo Considerations of wothod." MationaI soelety for the study of Education, iventy-ninth rearbook, Yart II, Public school rablishing Company, BloomIngton, I111no1s, 1930, P. 224.

Tewey, John, Hol we quink, D. C. Heath and Company, Hev Yoxk, 1910, P. 224.

3schor 11ng, Halph and Edmonson, J. B., "ithe Techniques of rextbook Authors." National soclety for tho study of Education, whirtioth yearbook, Part 1I, Public school rublishing Company, Bloomington, Illinols, 1931,

Pp. $44-45$. 
the problow of Individual differences; (3) Hev-type tests-inventory, diegnost1c, and remedial; (4) Certain exercises specially designed to increase the pupil's ability in problem solving; and (5) kfforts to carry out a definite program of motivation. According to Wae ${ }^{1}$ the problem in seventhgrade mathematics over which teachers seemed most concermed was how to interest the children in the practical aspocts of thematios without sacrificing such drill 28 is necessary for accuracy and factilty in the fundamontal processes. Whe says that it 1s necessary to give a considerable number of seventh-grade pup1ls more than a brier review of the fundamentel processes, but ho also recognizes that the attainmont of praotical rasults that eamot be secured from routinized drill alone 18 also desirablo.

In sereral of the centers where Lide visited he made an offort to conduct drill in suoh a wo that the course of study did not become too mochanical or tiresome for the pupil. In three of these centers the schodules provided that ten minutes of each perlod bo devoted to drill.

In Boston, dr11l was connectod in many ways with an alm at dereloping what the junior high school

1Lide, E. S., "Instructor in Mathomatics." United states Department or the Interior, uffice of Education, Bullotin wumber 17, monograph number 23, 1932, Pp. 30-32. 
teachers called "mathomatical sonse". Whore possiblo, they attempted to have the pup1ls take a common-sense vien of the application or mathematics to practical situations--a noed emphasized by many witers ou outIined above.

In constructing the course for junior high school mathomatics at the University of Chicago High school, Breslich' found that pupil offlolenoy could be secured best through seomingly incidental reviows in practical situations. In consequence, much that had been done in the erithmetic classes previously was omitted.

According to the Loulavilie course of study, drill 18 tremondously important, though "a good drillmaster is not necessarily a good teacher".

$$
\text { In terms or the Indianapolis course or. }
$$

study", "An important feature of the course is provision for frequent roviows and systematio arill in the frudamentel operations at regular intervals throughout the course. By contering attention upon relatively fer out-

IBreslich, H. R., "Koeonstruction in seoondary school thomatics, Ph. D. 'thesis (Jnpublishod), University or Ch10ago, 1926.

Rouiaville rublic schools. Mathematics--Hentative Course of study for Juntor High schools, Grades VII and VIII, Louisville, Kentuckg, 1933.

3indianapolis Fublic schools. Course of study in uathomatios for the Junior H1gh school DIVision of the secondary schools, Grades 7-8-9. Board of school lommissioners, Indlanapolis, Indiana, 1934. 
comos, and making adequate provision for effective motivated drill, a high degree of matery should be achleved.

X1X. The moderm seventh-grade arithmetic textbook should have inventory tests to determine wat the child lonows abcalt the sublect to be studied. 1

All the courses of study examined and the articles dealing with testing emphasize the med for inventory tests.

XX. the modern seventh-grade arithmotic textbook should provide inventory testing as a means of determining the child's alfficulties."

Practically all the literature examined stressed the importance of diagnostic testing in arithmotic. If an arithmetic textbook is to be in stop with modern oducational thought it must provide a diagnostic testing program that will bo readily arallable to the teacher and that will impress the child with his difficulties.

XXI. whe moderm seventh-grade arithmetic textbook should provide remodial tosts for particular ar1ll on the diffioultios discorered the diagnostic tests. ${ }^{1}$ since remodiel work is so potently important

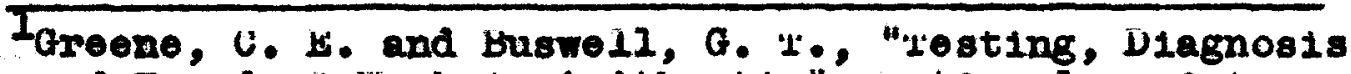
and Remedial Work in ArIthmotio", wational society for the study of kducation, wenty-ninth yearbook, rablic school rublishing company, Bloomington, IIllnois, Part II, 1930 , Pp. 269-276. 
and since teachers cannot be expected to be acquainted with remedial procedures not supplied in textbooks, it is erident that the textbooks themselves should provide the tests for this purpose. If remedial testing is loft for the teacher to outline or if remedial tests mast be purchased separateif from the textbook, it is quite certain that the needed remodial work will not be done. XXII. Hests provided by the modern seventh-grade ar1thmetic textbook should be of both types: ${ }^{1}$ "ithe shortanover objective test which covers a larger range, and the trpe of question calling for sustained applioetion."

While it is apparent that the short-answer objective examination is hore to stay, there is an increasing dissatisfaction with it as the sole measuring device. inls is most apparent in the writings of teachers and in the courses of study examined. Evidentiy, the moderm true-false, multiple-cholce, and completion tests do not test all that teaching experience indicates is accomplishod In the learning process. Modern thought requires that the text provide adequately for testing by both mothods.

IUn1versity of the state of wew York. A lientative sillabus in Junior High school mathematics. 'the University of the state of Men York Press, 1 lbany, NOW York, 1928 (rorerord). 
XXIII. whe modern serenth-grade arithmet10 textbook should provide for indiridual differences."

the recognition of individual differences is one of the outstanding achievements of moderm times. It is now clearly understood that children differ in ablilty and that equal amounts of instruction cannot result in ldentical products. 'through a combination of several criteria--achiovement tests, previous school records, teacher's oplnions, and such, it is possible to classify children according to thoir various abilitios in a way that is distinotis modern. To olte the literature in this field would be impossible in a limited space; to cite that reviewed in this study would almost moan giving the ontire list of referenoes contained in the bibliography. 'lo determine how children should be taught after they have been classifled is one of the major problems of textbook witers. Some writers have adopted various plans by which they hope to increase the teacher's skill with children who differ markedly in ab1lity. Practically all writers have proxd ded some practice tests of graded diffieulty. whose tests aim at giving each child an opportunity to make his best individual progress.

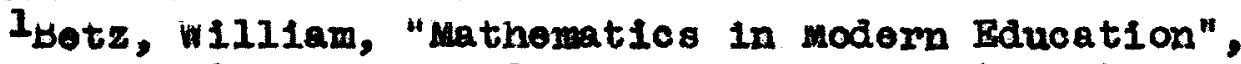
the rational counoil of reachors of thematics, Eleventh yearbook, Bureau of Publioatlons, 'Heachers' Colloge, Now York, 1936, Pp. 93. 
Some authors provide several lists of miscellanoous review problems at the end of a topic whose difficulties have been determined experimentally. 'Ihere may be a list of problems designated as "Easy", another list for the average pupils and a third list for tho superior studonts.

the san rrancisco course of study ${ }^{1}$ makes deta1led prov1s1ons for slow-moving groups, marking those portions of the work which may be omitted by these groups. They place major emphasis on the, necessar1ly, over-changing nature of the ourriculum.

the provisions made for individual differenoss reflect, perhaps, more than any othor prov1810n, the carefulness given to coursemor-study construction. rhere should bo specific meterial included for the purpose of the laboratory-plan of instruction. The ultimate aim should be for a variety of activitios, many of which have been tested carefully, and which will ald in the attainmonts of spocific loarning such as factual knowlodge, habits and attitudes. Relative to this subject, the Indienepolis Course of study says : ${ }^{2}$

Isan Francisco rublic schools. Mathomatics, Junior H1gh school, Grades VII, VIII, and L, Currioulum bulletin wumber 108, Board of Bducation, san vranc1sco, 1927. Indianapol1s rublic schools: Course of study in wathematios for the Junior High sohool Division of the secondary schools, Grades 7-8-9. Board of school vomm1ssioners, Indianapolis, Indlana, 1934. (Foreword). 
"Sinee the lengthened class period 1s used In the serenth and eighth grades, practical1y a11 of the work 18 done under the immediate supervision of the teacher. Ihis enables the teacher to spend at least half of the class period in supervised study and affords an opportunity for her to help those pupils who encounter alfficulties. Since the emphasis is largely upon the application of fundamental skills to new situations, it 1s relatively easy to adapt the rork to the ability and experience of the Individual pupil. tho slower pupil can be given problems involving the more - lementary applications, whlle the stronger pup1l can be assigned more difficult exercises. 'l'he work in the classroom involves both group and Individual aotivity. In developing an understanding of the soclal background for the methematioal operations, for examplo, the class: should work largely as a group, In aoquiring thematioal sk111s the work should be individualized to a Large extent.

XXIV. whe modem seventh grade ar1thmetio textbools should be organized on a "Unit plan."

the courses of study available and most of the educational 11terature reviewed mention or emphasize the desirability of the init plan of organization.

\footnotetext{
Indlanapol1s tubl10 schools: Course of study in mathemat1es for the junior Hioh sehool Div1sion of the secondary sehools, Grades 7-8-9. Board of schoo I commissioners, Indianapol1s, Indiana, 1934. (Foreword).
} 
The courses of study outline their work in "Onits". According to the Indianapolis Course of study there are soveral advantages to such organization. 'they say: "Iho materials in the seventh and eighth grades have been organized around such toples as taxes, selling, lines and angles, and plane and solid rigures. simple application of the formula and simple algebraic -quations are introducod in appropriate connoctions. "iho waterials in the seventh and eighth grades havo boon divided 1nto fall and spring somosters In order that " $A$ " and " $B$ " pupils in each grade way bo combined when nocessary for instructional purposes. In order that this arrangement will not hanaloap the pupils who take the spring somester prior to the fall semester the materials have been organized so that tho work in one sompter is not ossentialis a foundation for the work of the other semester in the same grade. Since the " $A$ " and " $B$ " pupils will not have the same background it 1s vital that the drill materials whioh aro introducod to maintain the skills acquired in the previous semesters be planned separately for the two groups, - each according to the background of the particular group." that the umit plan of organization 1s a product of modern educational thought is further indicated by

Indianapolis rublic schools: Course of study in Yatreatios for the Junior High School Division of the secondary schools, Grades 7-8-9. Board of school lommissioners, Indianapolis, Indiana, 1934. (Horeword) 
the emphasis fiven it in educational courses in the miveralties. Ihe miter of textbooks of today should take these 1deas into consideration in preparing a textbook for today.

XXV. the modern seventh-grade arithmet10 textbook should have Its subject matter integrated with other subjectEtter and with vocetional fields.

Acoording to the Oakland course of study the major objective of mathematics 18 integration with ife activities. 'they say that the course, and of course the textbook, should: "(1) Have Immodiate value rather than alm at preparation for more advanced courses; (2) be logical mathomatically and at tho samo timo consider the soolal needs of the child; (3) Include: the elements of simple arithmetic, intultive geometry, algebra, statistios, and numerioal trigonometry; (4) Be mifled; (5) Kesult in accuracy; (6) Havo social ut1L1ty." whe detail in which they outilne the content of the seventh-grade arithmetic course should be a marked holp to the teachor, should aid materially in selecting textbooks for this course in the vakland schools and should bo of distinct ald to an author writing a book he hoped to sell to the Oakland system.

IOakland rublic schools. Mathomatics for Junior High Schools. Superintendent's Bulletin, Course of study Serles wumber 103. Board of Education, vakland, Cal1fornta, warch, 1927. (foreword) 
According to the Loulsville lourse of study, integration must be sat1sfactory. Unfortunately, there 1s little or a definite nature to show how this 1s to be accomplishod. Ihey quote from the wational Comaltee of mathomaties Requirements (Roorganization of mathomatios in socondary Education, Chapter II, P. 13) that, "Ihe primary purpose of the teaching of themat1es should be to derelop those powers of understanding and of analjzing rolations of quantity and space which are necessary to an insight into the oontrol over our environmentr--."

Bven a cursory examination of modern educational literature shows that a great deal of importance 1. attachod to the integrating of subject matter or one course with that of otherg and of relating the whole to tho rocational aspects of adult ife. That this is very inadequately done in the moders serenth-grade arithmotic textbook $\mathbf{w 1 1}$ bo show in chapter IV. XXVI. The modern seventh-grade arithmetic textbook should hare proper balange betreen adult- and child interests.

Wh1le there is no specilic reference in tho 11terature as to just what percent of the rork in the

ILouisv1110 Fublic schools. Wathematics--1entative course of study for Juntior High schools, Grades VII and VIII. Board of Education, Loulsvilie, Kontucky, 1933.

EBuckingham, H. K., "the soolal Vaiue of Arithmetio", National society for the study of Heucation, irentyninth yearbook, Public school rablishing Company, Bloomington, Iilino1s, Part II, 1930, Pp. 95-96. 
course should center about enild interests as opposed to adult interests, it is mentioned, rather inc1dentally, that neither muat be emphasized to the exclusion of the other. At the sane time that the author motivates pup11s through appeals to the activities with wich they are intimately acquainted as children, ho should acqualnt thom with and prepare them for adult activities. It might be reasonable to place a good portion of the responsibility of acquainting the child with vocations which he might consider following upon the rriters of the textbooks ho studies. some of the confusion in choosing rocations and the lack of Information about rocetions or today results from fallure of textbooks to moet this requirement. XXVII. Whe modern seventh-grade aritbmetie textbook should: (1) Revier the rumdamentals: (2) Introduce the AIgebraic Hormula: and (3) Give more attention to intultire Geometry Mnan is Gnstomary. 1 the courses of study examined are in complete agreement on these points though they do not agree in total as to how mach revien should be given. whow alsebra should be introduced, or how much timo should be devoted to intuitive geometry . A somewhat typical time allotment is given in the Indianapolis

\footnotetext{
Indlanapolis tablic schools: Course of study in mathemetics for the Junior High School Division of the secondary sohools, Grados 7-8-9. Board of school Commlssioners, Indianapo11s, Ind1ana, 1934. (Forevord)
} 
Course of study. It follows:

\section{SEVENTH GRADE - FALC SEMESTER}

Unit I----literal vumbers, the Hormala,

and the Equation............4 Weers

Unit II----Buying and seli1ng

subun1t A-n--rercentage.............4 Weeks

subun1t b-..--Irade D1scount............2 Weeks

subumit $\mathrm{V}-$-.-Commision..............4 Weeks

subunit $D-\ldots-$ Gain and loss............ Weoks

Revier.................2 Weeks

SEVENTH GRADE - SPRING SEMESTER

Onit $1-----$ Lines and Ang1es..............5 Weoks

Un1t $11---m$ Lane rigures

subunit A-..-Quadrilaterals............ Weoks

Subumit B-n--lirianglea...............2 Wooks

Un1t III---stat1stios and Graphs........... Feeks

Un1t IV----Household Practices

subunit A-.--buagets.................. Weoks subun1t $B----$ Arithmet1c of the Home.....2 Weeks

Rev1ew...................2 Weoks

XXVIII. Mechan10ally, the modem seventh-grade arithmetio

textbook should:

1. Have an attractive and durable binding.

2. Have paper of appropriate ma11ty and rejent. "

3. Have ten or eleven point trpe. 2

4. Hare lines abont 80 millimeters in longth.

Indlanapolis rublic schools: course of stuar in lathematics for the Junior High school Division of the Becondary schoola. Grades 7-8-9. Board of school comm1s810ners, Indianapol18, Indiana, 1934. (roreword)

Rilnker, A. and raterson, D. G., "Studies in 'Iypographical ractors Influencing speed or Reading." dr. of Applied rsychologx. Volume XIII, Number 3 , Jume, 1929, P. 212. 
5. Have pages that are nor crowded.

6. Have attractive 11lustrations.

7. Have 1llustrations that holp pupils visualize 11fe interest of problems.

8. Provide a protractor w1th the book.

Generally speaking, the mechantcal foatures of modern textbooks are superior to their educaticnal and psychological aspects. 'textbook publishers have been more alert regarding mechanical aspects than any other feature of their books. Ihen, the criter1a of sound mochanical construction are fairly definite whilo oducational and paychological oriteria, even though avallable, are hard to apply. For the most part, the oducational literature merely mentions the aspects of satisfactory mochanical construction. It is almost taken without proor that the s1ze of type should be about ten point (two millimoters high), that there should be a good deal of space between letters, words, and lines, that the lines should be in the neighborhood of olghty millimeters in length, that the papor should have a dull finish. ${ }^{1}$

While 1t costs $108 \mathrm{~s}$ to stitch a book than to 2

sew 1t, and the stitchod book is moxe durable, many

$I_{\text {lackiosh, Mo and moss, F. K., seelng, A Partnorshlp }}$ or Lishting and V1sion. Wililems and WIIkins lompany, Baltimore, 1931, Chapter XII.

Z Fulier, Florence, Solentific Evaluation or rextbooks. Hought on iffin company, Boston, 1928, P. 49. 
books are sewed bocause they present a sightly better appearance and open more eas1ly. The stitchod book is reconmended, however, because of 1ta greater durablilty.

It is generaily agreed that the color of a textbook should be dark, though this is not as 1mportant now as formerly due to the development of washable covers.

Acoording to lide ${ }^{2}$ there is an increasing carofulness in the meohanical make-up of course outlines as a moans of maing thom more attractive and usable. He says that outlines should be made attractive as well as forceful through the use of mochanical alds, and should provide space in wich the teacher's criticisms may be recorded. The modern seventh-grade arithmet1c textbook should opeervo the same prinolples. XXIX. Summary:

Draper and Roberts ${ }^{2}$ saj, in substance, rolative to the selection of textbooks :

By whom was the book witten? what is his philosophy and experimental work done in proparation for writing such a book?

By whom has the book been published? Many of our book companies have becomo spocialists in certain

\footnotetext{
Ilide, E. S., "Instructor in mathomaties." United states Vepartment of the Inter1or, Uffice or biducation, Bulletin mumber 17, nonograph mumber 23, 1932, Pp. 17-18. LDraper, K. M. and Koberts, J. L., Princloles of American secondarn Eduontion. Appleton-lentury Compan, New York, 1932, p. 387 .
} 
rields or at least have made cutstanding contributions in publialning textbooks for these flelds. whey havo secured mon of national roputation to odit for them in these flelds, and for these reasons should receive more than usual conalderation.

How nearly does the content of a particular book make possible the realization of the objectives of the course of atudy which has been worked out in the school? the number of pages devoted to each tople should be Ilsted as the basis for comparison. the number, distribation, and desirability of 11lustrations should be checked. In simlar manner, the dri11s, tests, and problems should be giten careful attention.

Is the general organisation of the book suoh that it w111 moet the needs of the chilaren of the particular grade, age, and level of ablilty for which It is being considered? In this connection, the a1ze of type used, the quality of paper, the quality and number of 11lustretions, whe durability of the binding, and the isze of the book should be considered.

If the book should be selected, roula it be adaptable to all the chlldren of a particular age and grade, or suited only to the neods of certain ability 1eveIs? 
Jacobs ${ }^{l}$ lists features outlined by vraper and Roberts and supplements them somewhat as follows: (1) Doos the euthor's point of view best serve the present neods? (2) Does the subject matter of the textbook conform with both progressive educational theory and looal oducational a1ms? (3) yoos the toxtbook appeal to the interests of children? is it interesting, ongaging, appealing, and does it make proviston for individual differences while bullding good study habits? (4) Doos it save the teacher's time by careful planning, abundance of material, simple but effective tools for learning and convensent "units"? the organization of subject matter should be considered carefully. the author may have approached the material from the standpoint of logical development of subject tter but with little thought about the learner. 'the only way to determine the sultablilty of a textbook from the atandpoint of organization is to make a careful and complete analjsis of the content in the light of the students who $\mathbf{1 1 1}$ study the text. Analytical summary of the literature shows that the modern seventh-grade arithmetic textbook should:

1. Have a sound phllosophical background relative to the functions of aritmotic.

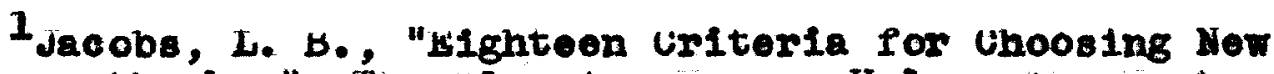
lextbooks." The ciearing House, Volume 11 , Number 8 , Apr11 $1937, \mathrm{Pp} \cdot 485-486$. 
2. Provide a sound system of character and citizenship training.

3. Be understandable to seventh-grade chilaren-have a rocabulary of suitablo diffloulty.

4. Have brier, simple, and unified sentences and paragraphs.

5. Define new terms in context as they are introducod.

6. Provide motivation through data related to the ch11d's experionoe.

7. Address explanations to the child rather than to the teacher.

8. Provide 1llustrations that visualize 11 fe situations for the child.

9. Provide gamos and contests to meak the monotony.

10. Provide adoquate opportunity for practice in problem solving.

11. G1ve a good deal of attention to the mathematios of thrift and investmont for overy dey use-banking, interest, savings, discount, brigets, etc.

12. Provide concrete problems which require actual mosurements to bo made, estimates given, etc.

13. Instruct the pup11 for 1mmediate and future use of graphs and formulas, onablo him to interpret them intelligently in his reading of nowspapers, magazines, and other ourrent literature. 
14. Provide a great number of reasoning problems involving life stutions.

15. Have drills that will iron out difficultios and wake correct mothods moohanical.

16. Have drills distributed in diminishing amounts and at more frequent intervals.

17. Provide for drill, in amount, proportionate to the diffloulty of operation.

18. Ose "m1xod" rather than "1solated" dr111s.

19. Have inventory tests to determine what the child knows about the subject to bo studied.

20. Provide diagnostic tests as a means of determining the child's diffieulties.

21. Provide remedial tests for particular drill on the difficulties discovered by diagnostio tosting.

22. Provide tests of both the short-answer objective type wich cover a larger range, and the type calling for sustained application.

23. Provide for individual differences.

24. Be organized on "Onit" plan.

25. Integrate its subject metter with that of other courses and with rocational fields.

26. Have a proper balance between adult- and childinterests.

27. (a) Rev10w the fundamontals; (b) Introduce the algebraic formula; and (c) Give more attention 
to intuitire geometry than is customary.

28. (a) Have an attractive and durable binding;

(b) Have paper of appropriate quality and welght;

(c) Have ton or eleven point type;

(d) Have lines about elghty millimeters in lenth;

(e) Have uncrowded pages;

(f) Have attractive 1llustrations;

(g) Have 1llustrations that visualize the 11feinterest of problems; and

(h) Provide a protractor with the book.

That these features should characterize the modern seventh-grade arithmotic textbook is adequately shown by moderm educational and psychological literature; the extent to which these requirements are wot by modern textbooks of arithmetic at this lovel 18 shown in Chapter IV. 
CHAPTER IV

ANAIYSES OF' SIX MODERN SEVENTH-GRADE ARITHMETIC TEXTBUOKS

Introduction:

In order to determine how adequetely the modern seventh-grade arithmotio textbook moets the requirements of modern educational thought as to what a serenth-grade arithmetic textbook should be 11ke, detalled analyses were made of the six such books 11sted in the Cumulative Index of Periodic Literature for the Joars 1934 and 1935. Who textbooks, 1isted in the order in wich they are discussed throughout the study, are:

1. Edgerton, E. I. and Carpenter, P. A., the Ner Mathemat1es. Benjamin H. Sanbom and Co., Chicago, 1935.

2. Brucoloner, L. J., Anderson, C. J., Banting, G. O., and Werton, E. I., the Ner Irianglo Arithmotics. John C. Hinston Co., Chicago, 1935.

3. Stono, J. C., Mills, C. ., and Mallory, V. S., Uait Matery Wathematics. Benjamin H. Sanborm and Co., Chioago, 1935.

4. Thompson, C. 0., Elements of Prectiegl Arithmotic. Prent10e-Ha11, Inc., New York, 1935. 5. Schorling, R., Clark, J. R., and smith, R. R., Hodem Sehool Mathemat1es. World Book Co., Yonkerson Hudson, wew York, 1935. 
6. Strajer, G. D. and Upton G. B., Practical Arithmotic. Amorican Book Co., Chicago, 1934.

Reasons for limiting the books analyzed to those listed above are given in Chapter I of this study. The six textbooks were given oritical oxamInation by the writer individualiy on each of the foatures listed in chaptor III as requisite to the modern seventh-grade arithmet10 textbook. On a.1l of the eriteria which seemed to admit of such prooedures, or whore the judgments of more than one person would improve the value of ratings, the six textbooks were rated in order of merit by rive teachers of seventhgrade arithmotic in the Loulaville Public Schools. "the "rators" worked independently, using the detalled instructions given in Appondix C. A threo-point scalo of merit (Abore Average, Average, Below Average) was used because the concensus of opinion of the five fudges and of several other experieneed teachers was that three degrees of merit were about all that could bo kept in mind and that three orders of morit constituted as fine distinctions as could be made with adequate accuracy. whe validity of these ratings is discussed in Chapter I; that thoy are reliablo is ev1denced by the very close agreement between the ratings of the five judges as given in table 29. Analyses are givon under the hoadings, I to 
XXVIII, Inclusive, given in Chapter III. Data a ro prosented in tables and sumeries, and spocific indication is given as to whether the judgments aro opinions of the writer, Individual judgments of the five "rators", or combined judgments of the five "ratars".

I. Philosophical background of $81 x$ moderm seventh-grade ar1thmotic textbooks:

In the opinion of the witer, an adequate analysis of the general philosophlcal beckgrounds of those six textbooks is 1mpossible. While the Preface or Introduction of each gives a short treatise on the place of arithmetic in the currioulum, what it $1 \mathrm{~s}$ hoped the child will learn in the course, etc., these discussions are addressed to the teacher rather than to the pup1l, perhaps justifiably so, and are too incomplete for analysis.

Some indieation of the philosophical background of the books may be had from a lmowledge of the backgrounds of their respective authors. Unfortunatels, the training, experience, and educational philosophles of the authors are not avallable in connection with the textbooks in such a mer as to make proper examination of these possible. On the basis of academio position, the authors of Book II should form a better belance of oducational philosophy and actual contact with practical school situations. 'the authors are, respectively: 
Professor of Flomentary Education, Dean of a School of Education, Superintendent of Schools, and Elemontary supervisor. 'Ihe positions held by the authors of the six books are given below. If the academic position of an author is representative of more than one fleld he is tabulated under each. The total number of authors and of flelds ropresented is also given.

Books

F101ds of Authors

Dean of Education

Profossor of Education

Professor of Mathomatics

Superintendent of Schools

High School Prinolpal

Supervis or

High School Mathemat10s

High School, Unclassified

Publ10 sohool wathomat10s

Public school, Unclassiflod

Number of Authors

Number of Field:
I II III IV V VI 1

1

11

13

1
1

1

1

1

2

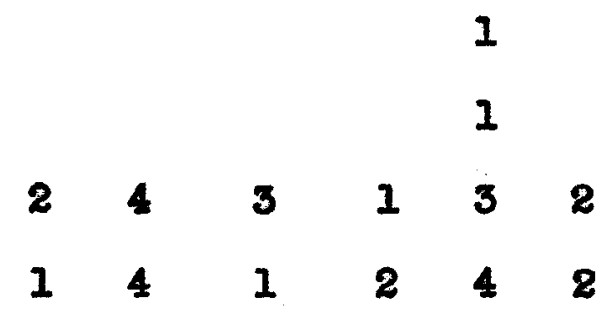

That the authors of several of the textbooks examined are ominently qualified, from the standpoint of educational training bo implied from their roputations in the field of modern education. What other authors, not so eminent in modern oducation are any less 
qualified in this respect, is not demonstratable, howover. I'here 1s, of course, some justification for giving the ominenoe of textbook authors weight in evaluating their products. It is not to be supposed, however, that an eminently qualified author will invariably produce an exoellent textbook. A more adequate mothod is to examine the textbook itself to determine whother the principles of modern educational philosophy have been followed. I'his is done in succooding soctions of this chapter.

II. Provisions for oharactor and citizenship training in the six modern seventh-grade arithmetic textbooks.

So far as the writer is able to determine from careful examination of the six textbooks there is no consolous offort to develop the characteristics of good character and citizenship--industry, Cooperativeness, Courtesy, Honesty, Dependability, In1tlative, Self-Control, Moral Courage, Loyalty, Reverence, Tolerance, Aesthetie Approciation, Optimism. If these are to result from the teaching of arithmotic where these textbooks are used, they must come from the teacher and not from the textbook. In view of the crying need for training in character and citizenship this $1 \mathrm{~s}$ most unfortunate. Considering the findings of Hartshorne and Hay $^{1}$

\footnotetext{
1Hartshorne, Hugh and May, M. A., "Studies in Decelt", Studies in the Nature of Character, Book $I$. 'I'he Vacmillan Company, Now York, 1931.
} 
that character traits are pretty mich apecirio to situations, efforts should be made for training in honest calculations and to provide methods for determining wether the child was honest in those situations. III. 'the rocabulary of $s$ ix modern seventh-grade arithmet10 textbooks.

In analyzing the vocabulariea of the $s i x$ arithmetic textbooks the miter chose selections from each totalling about 300 words in length. (Appendix A) A term was counted as a word whether it had one, two or ten letters in 1t, the length of the rond not being taken into consideration.

The selections included materials on percentage, interest, bank alscount, budgets, and banking. These topios rere used in order to secure selections which would be freo from problems and oomputations and wich would be about the same subjects for al1 the textbooks. "these aiscussions, of necessity, were widely seattered throughout the book and, in the opinion of the writer and four other seventh-grade teachers of arithmetic, constitute representative samples of the rocabularies of the books. Iho selections were ilmited to 300 rords in length in order to avold the use of numbers as far as possible and to secure comparable materials from the various books. 'the juages were the same teachers as 
those tho made the other ratings used in the tudy. they were in complete agreomont as to the representativeness of the selections used, since all 1tems on which they were not completely agreed as to representativity were excluded from the study. classffication of the words according to Professor 'thorndike's ${ }^{1}$ ratings as to frequeney of usage is given in trable I. the froquenoy-of-usage Groupings are given in the stub. The books (I to $V I$, inelusive) are given in the caption. I'he number of words falling in oach grouping is given, together with the percentage that these are of the total number of words in the seloction. Whe line between the 7001-8000 and 8001-9000 groups is drawn to omphas1ze the total number of words in the rocabulary of the average seventh-grade chlld at age thirteon jears-about 8000 words according to Terman". Ihis is an approximation of the difficulty beyond which mach of the vooabralary of seventh-grade textbooks should not 80 , considering the relationship between language mastery and frequency of usage.

Ithornd1ke, E. L., The Heacher's Word Book. I'eachers College, Columbia UnIversity, MeT York, 1923.

Z iperman, L. M., ithe Measurement of Intelligence. Houghton Miffin Company, Boston, 1916, P. 226. 
TABIE I

WORDS FROM REPRESENTATIVE SEIECTIONS OF SIX SEVENPH-GRADE ARITHMETIC TEXTBOOKS CIASSIFIED ACCORDING TO FREQUENCY OF USAGE

(numbers of words and percents that these are of total words in selections, Thornalke's Classification)

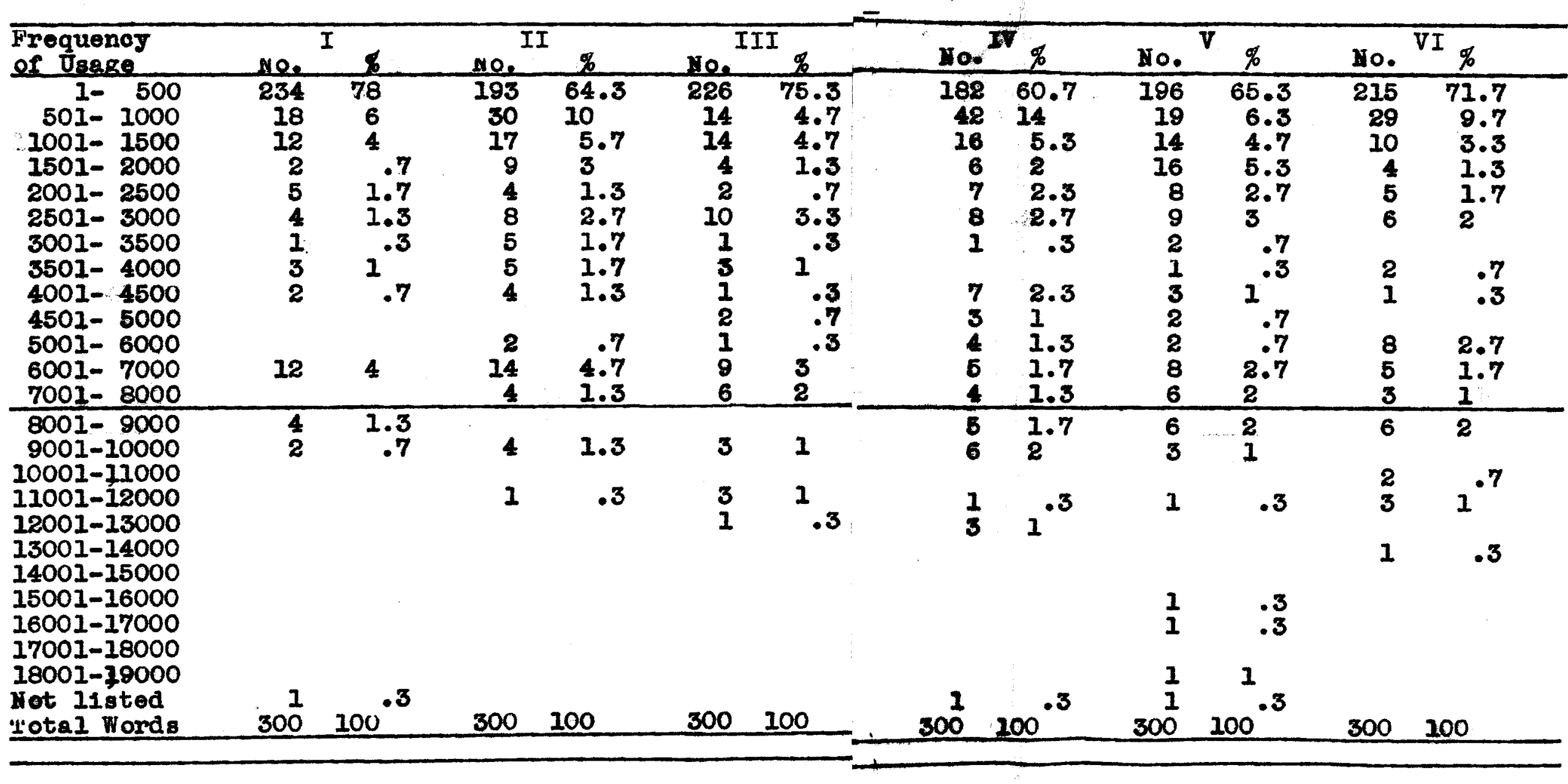


Whether the rocabularies of the six textbooks were "readable and comprehensible by seventhgrade chllaren", the threo judges rated them as fol10w8:

RATINGS AS TO SUITABILITY OF VOCABULARY OF SIX SEVENTH-GRADE ARITHMETIC TEXTBOOKS

(1 - superior, 2 = Average, 3 - Inferior )

Books

$\begin{array}{lcccccc} & \text { I } & \text { II } & \text { III } & \text { IV } & \text { V } & \text { VI } \\ \text { Juage A } & 3 & 1 & 3 & 3 & 2 & 2 \\ \text { Judge B } & 2 & 2 & 2 & 3 & 2 & 1 \\ \text { Judge C } & 2 & 1 & 1 & 3 & 3 & 1 \\ \text { Judge D } & 2 & 1 & 2 & 3 & 2 & 1 \\ \text { Judge E } & 2 & 1 & 2 & 3 & 2 & 2 \\ \text { Average } & 2.2 & 1.2 & 2.0 & 3.0 & 2.2 & 1.4 \\ \text { Rank } & 4 t & 1 & 3 & 6 & 4 \text { t } & 2\end{array}$

It should be noted that the ratings of the judges as to suitability of vocabulary agree vey woll with the vocabulary elassifications in torms of frequenoy of usage ('rable I) and with the average longths of sentences in representative selections from the books. ('Iable II) In the opinion of the "rators", those of the six books wich have shorter sentenoes and are more heavily loaded with frequently used words are more suitable to the neods of seventh-grade childron. It should be noted further that there is a close relation between implied philosophical background of the 
author (soction I of thls chapter) and the moasures of vocabulary and sentence sultability.

IV. the sentence and phrase construction of $81 x$ modern soventh-grade arithmotio textbooks.

As far as the witer could determine, the sentences and paragraphs of the s1x books are equally unified. There are marked differences between them as regards average length of sentenoes and of phrases, however. While length of sentenoe has certain woaknesses as a masure of diffloulty, it 18 generally agreed and has been shown in Chapter III that children learn more readily from compositions made up of short sontencos and phreses. I'his is, of course, in keoping with findings in the fleld of child development, that the longth of ldea that a child oan retain is determined, very largely, by his montal dovelopment.

In determining the lengths of sentenees for the selections from the six books five letters oounted as one word. Whe averages of sentence-length for the six books are given in 'Iable II, together with the standard deviations, standard deviations of the means, and probable errors of the means. 
IABIE II

CUMPARISUN OF SENPEMCE IENGTH IN REPRESENTATIVE SELECTIONS FROM SIX SEVENTH-GRADE ARITHMETIC 'LEXPBUOKS

$\begin{array}{rrrcc}\text { Book } & \text { Mean } & \text { S. D. } & \text { S. D.M } & \text { P. E.M } \\ \text { I } & 15.9 & 6.7 & 1.5 & 1.0 \\ \text { II } & 14.8 & 6.6 & 1.4 & .9 \\ \text { III } & 15.6 & 6.4 & 1.4 & .9 \\ \text { IV } & 24.3 & 9.4 & 2.5 & 1.7 \\ \text { V } & 16.3 & 8.8 & 2.0 & 1.4 \\ \text { VI } & 18.4 & 7.9 & 1.8 & 1.2\end{array}$

The question naturally arises as to the signifleance of these differenoes in average sentence length. 'that they may bo accepted, along with other factors, as ovidences of alferences in alfficulty has already been ahow in Chapter III. Whe stat1atieal olgniflcanse of the differences between moans is shom In table III. the differenees between auccessive mean sentence lengths are given at the left of the table. the means themselves are given in parentheses to make - lear how the differenees are obtained. Ihe probable orrors of the differences between means rere calculated from the regular formula:

$$
P B_{A-B}=\sqrt{P E_{A}^{2}+P E_{B}^{2}-2 P E_{A} P E_{B} P_{A B}}
$$

where PE refers to probable error of the mean, $A$ and $B$ to successive means and $\mathbf{r}_{A B}$ to tho correlation between

IDumlap, J. W. and Kurtz, A. L., Handbook of stat1stical Nomographs, 'l'ables and Formulas. World Book Company, Yonkers-on-Hudson, 1932, Formulas 254 and 5B. 
means. Since the means are uncorrelated, the thind term under the radical 1s, of course, zero. the probable errors of the means were caloulated from the rogular formula: 1

$$
\mathrm{PE}_{\mathrm{X}}=\mathrm{PE}_{\mathrm{X}} / \sqrt{\mathrm{A}}
$$

where $P E_{X}$ refers to the probable error of the diatribution and No the number of cases, In this instanco the number of sentences in selection. Probable errors of means were used since the differences to be interpreted are between means.

\section{IABIE III}

STATISTICAL SIGNIFICANCE OF DIFFERENCES BETWEEN MEAN SENTENCE IENGTHS OF REPRESENIATIVE SELECTIONS FROM SIX SEVENTH-GRADE ARITHMETIC TEXTBOOKS

(the suecessive subtractions of means are given in the stub, the means themselves being given in parentheses. 'The differences between means are given in the second colum, the probeble errors of these differences in the third column and the resulting quotients in the fourth colum.

Whether the difference is significant is indicated by "Yes" or "No" in the last colum.)

\begin{tabular}{ccccc} 
Subtractions & $\mathrm{d}$ & \multicolumn{1}{c}{$\mathrm{PE}_{\mathrm{d}}$} & $\mathrm{d} / \mathrm{PE}_{\mathrm{d}}$ & significant \\
$M_{1}-M_{2}(15.9-14.8)$ & 1.1 & 1.4 & .78 & No \\
$M_{1}-M_{3}(15.9-15.6)$ & .3 & 1.4 & .21 & No \\
$M_{1}-M_{4}(15.9-24.3$ & -8.4 & 2.0 & -4.20 & Yos \\
$M_{1}-M_{5}(15.9-16.3)$ & -.4 & 1.7 & -.23 & No \\
$M_{1}-M_{6}(15.9-18.4)$ & -2.5 & 1.6 & -1.56 & No \\
$M_{2}-M_{3}(14.8-15.6$ & -.8 & 1.3 & -.61 & No \\
$M_{2}-M_{4}(14.8-24.3$ & -9.5 & 1.9 & -5.00 & Yos
\end{tabular}




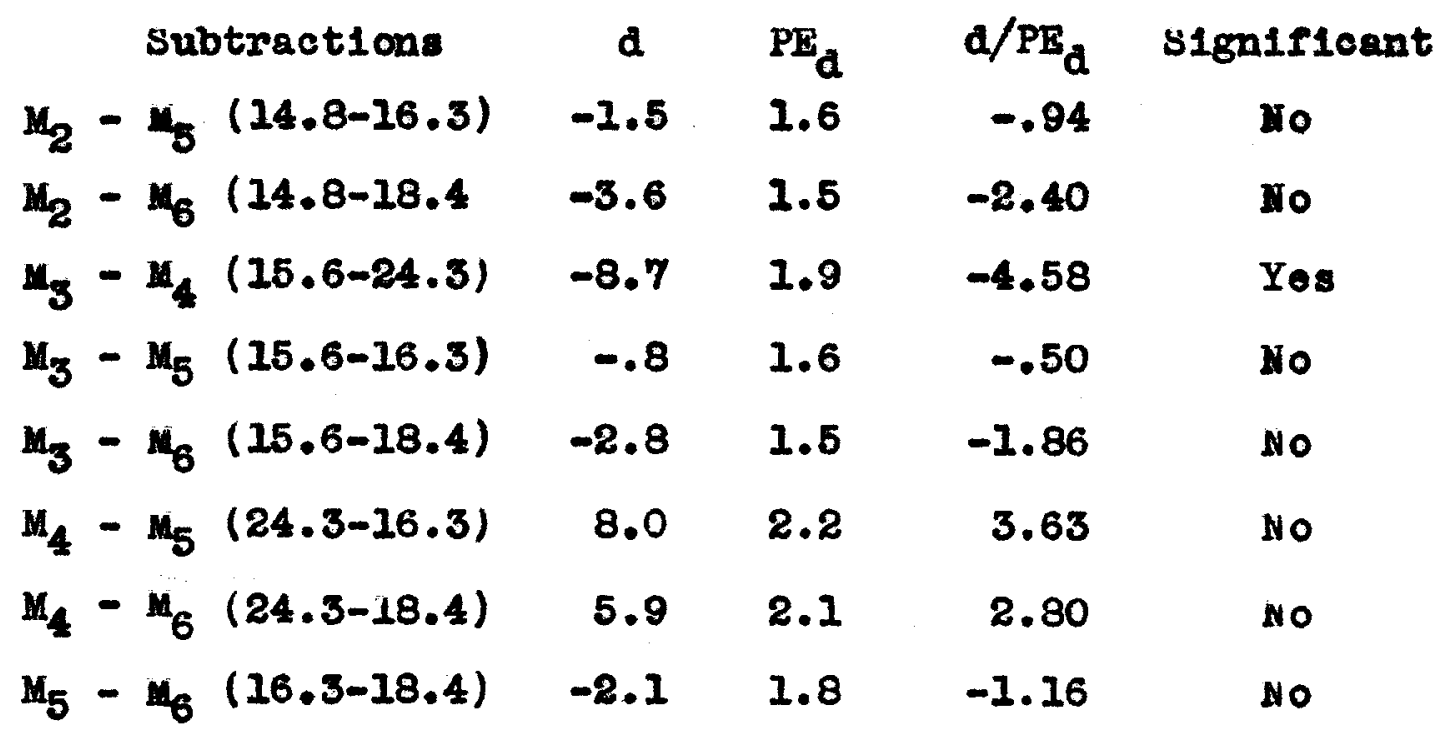

In reading $1 \mathrm{able}$ III note that the moan sentence lengths for the selections from the $81 x$ books are: $15.9,14.8,15.6,24.3,16.3$, and 18.4 the data for Book I mey be read and interpreted as follows

In length of sentences it averages 1.1 words longer than Book II, .3 words longer than book III, 8.4 words shorter than Book IV, .4 words shorter than book $\nabla$, and 2.5 words shorter than Book VI. 'the probable orrors of these mean differences as shown by Table III are 1.4, 1.4, 2.0, 1.7, and 1.6. Division of the differences by their respective probable errors are as show in the third row: $.78, .21,-4.20,-.23,-1.56$. since it is generally agreed that a difference mast be at least four times as large as its probable error to bo significant, wo may say that Book IV is the only ono having sentenoes of significantly different length from those of Book I. 
V. How adequately the six seventh-grade arithmotic textbooks derine now words in context as ther are introduced.

The opinions of the three judges on this

point are shown by their ratings given below:

RATINGS OF SIX SEVENTH-GRADE ARITHMETIC TEXTBOOKS ON DEFINING OF. NEW TERMS IN CONTEXI

( 1 = Superior, 2 = Average, 3 = Inferior $)$

Book I II III IV V VI

$\begin{array}{lllllll}\text { Judge } & 3 & 1 & 3 & 3 & 2 & 2\end{array}$

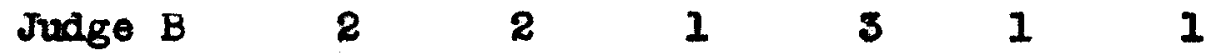

$\begin{array}{lllllll}\text { Judge } \mathrm{C} & 1 & 1 & 2 & 3 & 1 & 1\end{array}$

$\begin{array}{llllllll}\text { Judge } & 1 & 2 & 2 & 3 & 2 & 2 & 2\end{array}$

$\begin{array}{lllllll}\text { Judgo } \mathrm{E} & 2 & 1 & 2 & 2 & 2 & 2\end{array}$

$\begin{array}{lllllll}\text { Average } & 2.0 & 1.4 & 2.2 & 2.6 & 1.6 & 1.6\end{array}$

$\begin{array}{lllllll}\text { Rank } & 4 & 1 & 5 & 6 & 2 * & 2 \%\end{array}$

In the opinion of the writer, none of the books is satisfactory in this respect. they do not adhere strictly to modern educational opinion that now words should be defined as introduced, saving the child a great deal of offort and discouragement and obviating, vory largely, the use of the dictionary. It will be noted, of course, that Book IV is definitely inforior.

VI. Motivation through relating data to the ohlid's experlence. 
In examining for motivating provisions through appeal to Interest, Child Interest Problems were derinod as those dealing with objects or information of primary interest to children as:

"With a yardstick, moasure the length and widh of jour mathomatics room. Find the number of square foet to which each member of your olass is ent1tied."

Adult Interest problems were defined as those

of primary interest to adults, as:

"Hrs. H11l bought a vaouum cleaner having a 250 watt motor. She used it on an average of ten hours a month. If she paid $8 \phi$ per $K . W . H$. for - lectricity, how much did it cost hor to rmm 1t for a month?"

\section{Borderline Interest Problems wore defined as}

those holding interest for both adults and chilaren, as:

"Lindberth made the first reoord solo flight across the Atlantic. Ho flew 3600 miles in 33t hours. He averaged how many miles per hour?"

The fuiges rated the $s 1 x$ books relative to provision for motivation through appeal to child interests. wheir ratings are given below. Undoubtediy they considered factors other than the number or percent of problems devoted primarily to child interests since their ratings are not in complete agreement with the tabulations made by the miter as to what percent of the reasoning problems of the $s 1 x$ books were devoted to adult interests, child interests, and borderine interests. 
RATINGS OF SIX SEVENTH-GRADE ARITHMETIC TEXTBUOKS ON PROVISIONS FUR MOTIVATION THROUGH APPEAL TU INTERESTS

\begin{tabular}{lccccccc}
\multicolumn{5}{c}{$(1$ = superior, $2=$ Average, 3 Inferior) } \\
Book & I & II & III & IV & V & VI \\
Judge A & 3 & 1 & 2 & 3 & 2 & 2 \\
Judge B & 2 & 1 & 2 & 3 & 1 & 2 \\
Judge C & 2 & 1 & 1 & 2 & 2 & 1 \\
Judge D & 2 & 1 & 3 & 3 & 2 & 1 \\
Judge E & 2 & 1 & 3 & 3 & 2 & 1 \\
Average & 2.2 & 1.0 & 2.2 & 2.8 & 1.8 & 1.4 \\
Rank & 5 & 1 & 4 & 6 & 3 & 2
\end{tabular}

PERCENT OF REASONING PROBLEMS IN SIX SEVENTHGRADE ARITHNETIC TEXTBOOKS APPEALING TU CHIIDADUIH-, AND BORDERLINE-INTEERESTS

(Judgments of the witer)

Book I II III IV V VI $\begin{array}{lllllll}\text { No. Verbal Problems } & 1514 & 1272 & 945 & 1049 & 1643 & 932\end{array}$ $\begin{array}{lllllll}\text { \% Child-Interest } & 26.6 & 51.3 & 38.7 & 29.1 & 38.2 & 39.4\end{array}$ $\begin{array}{lllllll}\text { \% Adult-Interest } & 23.2 & 13.8 & 23.2 & 12.2 & 20.7 & 31.2\end{array}$

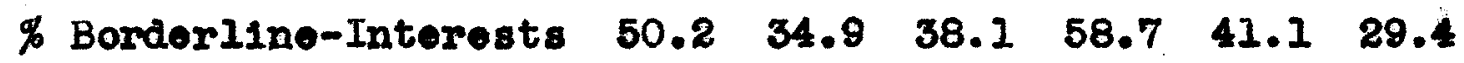
Rank $\begin{array}{llllll}5 & 1 & 3 & 6 & 4 & 2\end{array}$

It will be noted that the rankings of the texts from the two sets of data above are very close. As in most of the measures employed in this chapter, Book II is rated best and Book IV poorest of the six examined. 
VII. HOW sat1sfactorily the six soventh-grade arithmot10 textbooks address explanations to pup1ls instead of teachers.

As regards this particular foature, the judges rated the books as follows:

RATINGS ON ADDRESSING EXPIANATIONS TO PUPI LS RATHER THAN TO THE TEACHERS

(1 = Superior, 2 = Average, 3 = Inferior)

$\begin{array}{lcccccc}\text { Book } & \text { I } & \text { II } & \text { III } & \text { IV } & \text { V } & \text { VI } \\ \text { Judge A } & 3 & 2 & 2 & 3 & 2 & 1 \\ \text { Juage B } & 2 & 1 & I & 3 & 2 & 1 \\ \text { Juage C } & 1 & I & 2 & 3 & 1 & 1 \\ \text { Judge D } & 2 & 1 & 3 & 3 & 1 & 1 \\ \text { Judge E } & 2 & 2 & 3 & 3 & 2 & 1 \\ \text { Average } & 2.0 & 1.4 & 2.2 & 3.0 & 1.6 & 1.0 \\ \text { Rank } & 4 & 2 & 5 & 6 & 3 & 1\end{array}$

VIII. Adequacy with wich 11lustrations visualize life situations for the child.

The ratings of the judges follow: RATINGS ON ADEQUACY WITH WHICH ILLUSTRATIONS VISUALIZE. LIFE SITUATIONS FOR THE CHIID

(1 = superior, 2 = Average, 3 = Inferior) Book I II III IV V VI Judge A 3

II

Judge $B$

3

2

3

2

VI

Judge C

3

11

21

1

Judge $D$

21

21

21

2

Judge $\mathrm{E}$

1

1

2

31

3

Averago

2.4

1.4

2

32

2

Rank

5

1娄 3t

6 1* 
Book I has forty-one pictures and 11lustrations, not one of which, in the opinion of the writer, would help a child to visualize a life situation. Book II, on the other hand has thirty-two piotures and 1liustrations, many of which are pertinent to situations the child encounters in daily 11fe. Among the best of these are?

1. An inspector testing the accuracy of a grocer's scales.

2. A ploture 1llustrating the annual fire loss in various communitios.

3. An excellent diagram of a plumb-line.

4. A chart showing how we dispose of our com crop.

IX. Adequacy with which six seventh-grade arithmetio textbooks provide games and contests.

The ratings of the juages on this point

fol10\%:

RATINGS ON ADEQUACY WITH WHICH SIX SEVENTH ARIIHMETIC IIEXTBOOKS PROVIDE GAMES AND CONTESTS

(1 = superior, 2 = Average, 3 = Inferior)

Book I II III IV V VI

$\begin{array}{lllllll}\text { Judge A } & 2 & 3 & 3 & 3 & 2 & 3\end{array}$

$\begin{array}{lllllll}\text { Judge } B & 1 & 3 & 3 & 3 & 2 & 3\end{array}$

$\begin{array}{lllllll}\text { Judge } C & 2 & 3 & 3 & 3 & 2 & 3\end{array}$

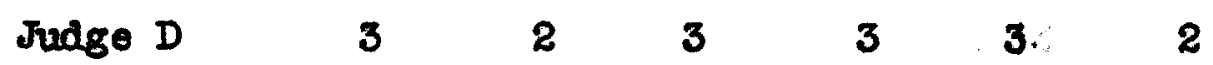

$\begin{array}{lllllll}\text { Judge } \mathrm{E} & 2 & 2 & 3 & 3 & 3 & 2\end{array}$

$\begin{array}{lllllll}\text { Average } & 2.0 & 2.6 & 3.0 & 3.0 & 2.2 & 2.6\end{array}$

Rank

$1 \quad 3 \frac{1}{2} \quad 5 \frac{t}{2} \quad 5 \frac{t}{2} \quad 2 \quad 3 \frac{1}{2}$


wone of the books is satisfactory in this respect. They overlook almost ontireit the possibil1ties of stimulating the ohild through competitive games and contests. While there are some provisions for interest through puzzlos in Books $I$ and $V$, these, at best, are woak attempts at conformity with modern oducational thought.

X. Provisions for problem solving in the six seventhgrade arithmotic toxtbooks.

In the opinion of the judges, all the textbooks were satisfactory and superior in their provisions for problem solving. 'the judges are in total agreoment that the books provide adequate opportunity, and they were unable to differentiate between the books in this respect. 'ihere was not this agreoment or satisfaction relative to the nature of the problems, however, as is shown in the next section.

XI. Extent to whioh the s1x serenth-grade arithmetio textbooks give attention to the mathematies of thrift and Investment for every day use.

The ratings of the juages on this point follow: RATINGS AS TO PROVISION FUR MATHEMATICS OF THRIFT AND INVESTMENI'

( 1 = Superior, 2 = Average, 3 = Inferior)

Book I II III IV V VI

$\begin{array}{lllllll}\text { Judge A } & 3 & 1 & 3 & 3 & 2 & 2 \\ \text { Judge B } & 2 & 1 & 2 & 2 & 1 & 1 \\ \text { Judge C } & 2 & 1 & 2 & 1 & 1 & 1 \\ \text { Judge D } & 3 & 1 & 2 & 3 & 2 & 1\end{array}$




$\begin{array}{lcccccc}\text { Judge E } & 2 & 1 & 2 & 2 & 2 & 1 \\ \text { Average } & 2.4 & 1.0 & 2.2 & 2.2 & 1.6 & 1.2 \\ \text { Rank } & 6 & 1 & 4 \frac{1}{2} & 4 \frac{1}{8} & 3 & 2\end{array}$

Since a large portion of all the textbooks examined is made up of problems, it is interosting horo to note the peroentage of each devoted to various topios. The writer went through each book carefully marking each problem, discussion, and example as to the field of arithmotio it dealt with. Whose wore tabulated and are presented below. PERCENT OF SPACE DEVOTED TO VARIOUS SUB JECTS
BY THE SIX SEVENTH-GRADE ARITHMETIC TEXTBOOKS Book I II III IV V VI Total No. Pages in Book $448 \quad 280 \quad 314 \quad 382 \quad 364 \quad 258$ $\begin{array}{lllllll}\text { Banking and Investments } & 6.8 & 7.7 & 9.6 & 9.5 & 6.9 & 15.6\end{array}$ $\begin{array}{lllllll}\text { Percentage } & 9.2 & 3.2 & 9.4 & 5.4 & 5.0 & 21.1\end{array}$ Stocks and Bonds 4.8

Insurance 3.0

Monsuration and Construction $\begin{array}{llllll}3.8 & 10.9 & 13.6 & 5.5 & 2.3 & 9.1\end{array}$ Graphs $\begin{array}{llllll}16.9 & 6.4 & 8.4 & 2.7 & 6.7 & 6.6\end{array}$

Budgets $\begin{array}{llllll}.5 & 1.3 & .6 & .7 & 1.2 & 2.7\end{array}$

Gas and Electricity $\begin{array}{llllll}1.2 & 1.8 & 3.2 & 1.9 & 1.2 & 3.5\end{array}$ Govt. Land Surveys .3

Motr10 system 1.6

T'axes 4.3

Geometry $\begin{array}{lll}3.6 & 4.7 \quad 13.6\end{array}$ $7.3 \quad 7.4$ Iransportation and Comminication 
It 1s signifleant that so 11ttio space is devoted to suoh subjects as banking and investments, stocks and bonds, and budgets, considering the importance of these fielas of thrift and investmont in the 11ver of American o1tizens. In consequence we find that the judges consider only one of the books (VI) auperior in its treatment of these topics. Ihere is indeed room for improvement in the modexn serenth-grade arithmetic in its provisions for thrift and investments. XII. Hor the six modern seventh-grade arithmetic textbooks provide concrete problems requiring actual measurements. estlmates, ete.

In the opinion of the juages, the books are about everage in their providing of oonorete problems. It 1s quite clear that the modern textbooks are not moeting the requirements of modern edueational thought in this respect. The ratings follow:

RATINGS AS TO PROVISION OF CONCRETE PROBLEMS BY SIX MODERN SEVENTH-GRADE ARIIHMETIC TEXTS (1 - Superior, 2 - Average, 3 Inferior) Book I II III IV $V$ VI

$\begin{array}{lcccccc}\text { Judge A } & 3 & 2 & 3 & 3 & 2 & 1 \\ \text { Juage B } & 2 & 1 & 2 & 3 & 2 & 1 \\ \text { Judge C } & 2 & 1 & 2 & 1 & 2 & 1 \\ \text { Judge D } & 2 & 1 & 3 & 3 & 2 & 1 \\ \text { Juage E } & 1 & 1 & 3 & 3 & 2 & 1 \\ \text { Average } & 2.0 & 1.2 & 2.6 & 2.6 & 2.0 & 1.0 \\ \text { Rank } & 3 \frac{1}{3} & 2 & 5 \text { 音 } & 3 \text { 竞 } & & 1\end{array}$


It will be noted that Book VI is rated as superior by all five of the judges. It 1s outstanding in the procedures by which the child is led to do actual work, moasuring, ostimating, ete., in solving his problems.

XIII. Provisions for immediate and future use of graphs and formulas in the six moderm seventh-grade arithmotic textbooks.

The ratings of the judges on this point follow. It $w 111$ be noted that Book II 1s agreed upon as boing superior. Books I and IV are rated as definiteit inferior.

RATINGS ON PROVISIONS FOR IMMEDIATE AND FUTURE USE OF GRAPHS AND FORMULAS IN THE SIX TEXTBOOKS ( 1 = super1or, 2 = Average, 3 = Inforior) Book I II III IV V VI $\begin{array}{lllllll}\text { Judge } A & 3 & 1 & 2 & 3 & 3 & 8\end{array}$

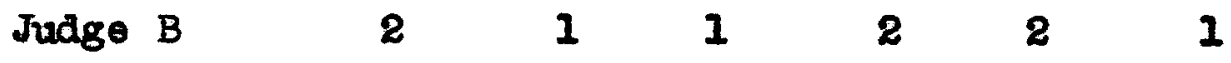
$\begin{array}{lllllll}\text { Juage } C & 2 & 1 & 1 & 2 & 1 & 1\end{array}$ $\begin{array}{lllllll}\text { Juage } D & 2 & 1 & 2 & 2 & 2 & 1\end{array}$

$\begin{array}{lllllll}\text { Judge } E & 2 & 1 & 3 & 3 & 3 & 1\end{array}$
$\begin{array}{lllllll}\text { Average } & 2.4 & 1.0 & 1.8 & 2.4 & 2.2 & 1.2\end{array}$ $\begin{array}{lllllll}\text { Rank } & 5 \text { 5 } & 1 & 3 & 5 \text { 㕝 } & 4 & 2\end{array}$

XIV. Provisions of the $81 x$ seventh-grade arithmetic textbooks for reasonging problems involving life situations. 
While there seems to be some overlapping between this desired feature of the modern seventhBrade arithmotic textbook and Number VI above, the Iiterature reviewed in Chapter III, separates the two to the extent that separate analyses seomed advisable. the ratings of the judges on this point follow: RATINGS AS TO PROVISION OF REASONING PROBLEMS INVOLVING LIFE SITUATIONS IN THE SIX SEVEATHGRADE ARITHMETIC TEXTBOOKS

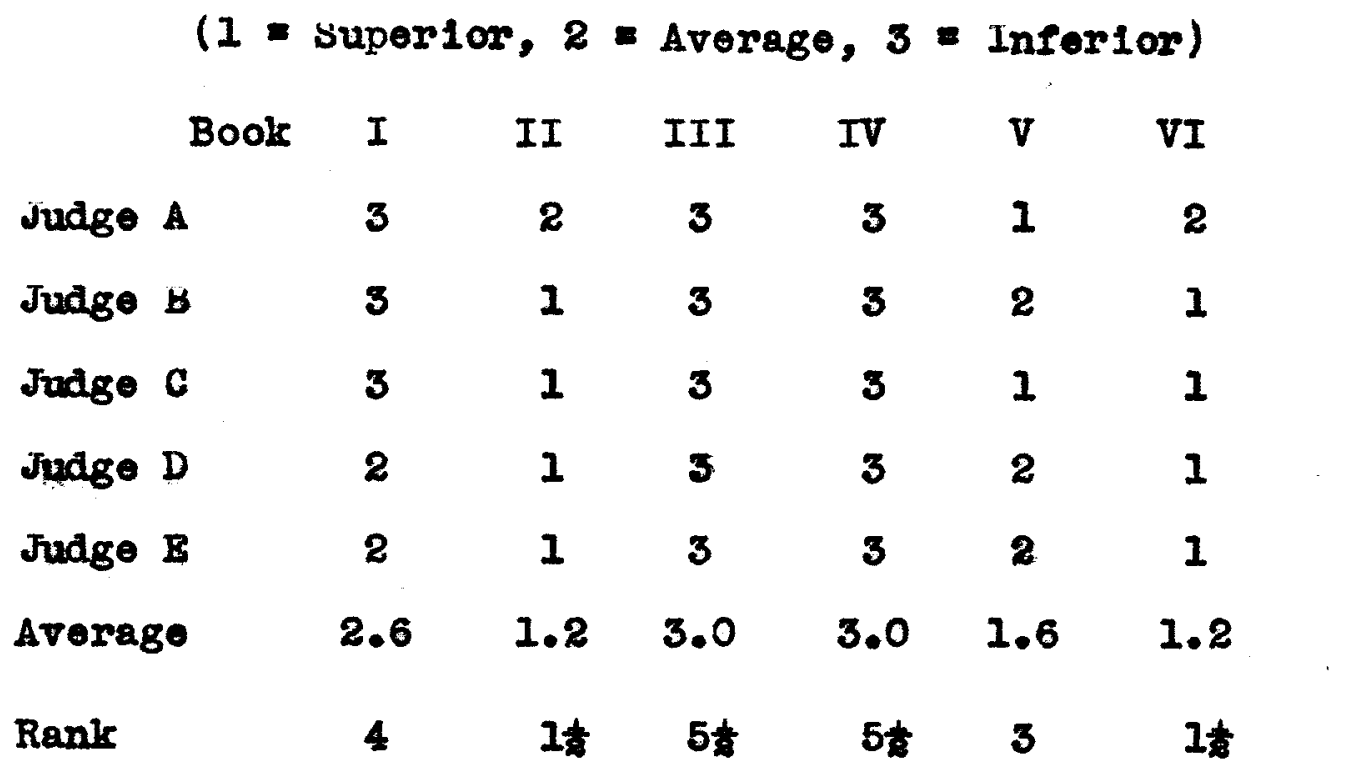

The ratings of the judges leave much to be done before textbooks in this field are abreast of modern educational thought regarding problems related to the lives of the children who atudy the books. XV. Adequacy of drills as regards amount in the aix seventhgrade arithmetio toxtbooks.

The importance of repetition, or drill, in learning, relearning, and retention, as emphasized in modem oducational and psychologieal literature was 
discussed in Chapter III. In order to determine how adequately the six serenth-grade arithmetio textbooks provide drills the writer oxaminod oach, tabulating the number of pages devoted to drill under the various subjects. those data are given below:

PAGES DEVOTED TO DRILIS IN THE SIX SEVENTH-GRADE ARITHMET IC TEXTBOOKS

$$
\text { I II III IV V VI }
$$

Total No. Pages in Book $448 \quad 280 \quad 314 \quad 382 \quad 364 \quad 258$

Accounta

38

Addition

4718

$5 \quad 11$

Aliquot Parts

3

2

1

Angles

$8 \quad 15$

7

47

Areas

5

12

59

Averages

36

Banking

2

Bills

3

Circlas

5

Construction

5

6

$3 \quad 11$

Decima1s

$\begin{array}{lll}7 & 28 & 5\end{array}$

$5 \quad 12$

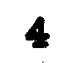

Diameters

3

1

Diseoumts

543

9

59

Division

54

35

Estimating

3

2

Fractions

$14 \quad 23$

8

$\eta$

156

Fundamentals

3

4

Graphs

Interest

$\begin{array}{llllll}3 & 3 & 3 & 5 & 6 & 6\end{array}$


Lines

Hetrie systom

3

Multiplieation

65

6

19

wumbers

$1 \quad 8 \quad 7$

Percent

7

$21 \quad 10$

$3 \quad 19$

15

Proceeds

2

Rat10

9

Rectangles

3

Sca 10 Drawing

3

Subtraction

$5 \quad 13$

5

12

iriangles

5

5

6

Zero Difficulty

21

Hotal Pages of Dri11

$\begin{array}{llllll}86 & 138 & 97 & 59 & 133 & 157\end{array}$

Percent of Bool

Devoted to Drill

$\begin{array}{llllll}19 & 49 & 31 & 15 & 37 & 61\end{array}$

Whe adequacy of these arills 1s, of course, a matter of opinion until such times as experimental ev1dence is ava1lable covering each of the situations. the ratings of the judges as to their adequacy follow:

RATINGS AS TO ADEQUACY OF DRIIL IN SLX SEVENTHGRADE ARITHMETIC TEXTBOOKS

\begin{tabular}{lccccccr}
\multicolumn{5}{c}{$(1=$ superior, $2=$ Average, $3=$ Inforior) } \\
Book & I & II & III & IV & V & VI \\
Judge A & 2 & 1 & 3 & 3 & 2 & 1 \\
Juage B & 2 & 1 & 1 & 2 & 2 & 1 \\
Judge C & 2 & 2 & 1 & 1 & 2 & 1
\end{tabular}




$\begin{array}{lcccccc}\text { Judge D } & 2 & 1 & 3 & 3 & 2 & 1 \\ \text { Judge E } & 2 & 1 & 3 & 3 & 2 & 1 \\ \text { Average } & 2.0 & 1.2 & 2.2 & 2.4 & 2.0 & 1.0 \\ \text { Rank } & 3 \text { t } & 2 & 5 & 6 & 3 \frac{1}{6} & 1\end{array}$

XVI. Distribution of drilis in diminishing amounts and at more Irequent interva is in the $11 x$ seventh-grede ar1thmet1c textbooks.

As to how adequately this is done, the fudges rated the books as follows:

RATINGS ON DISTRIBUTION OF DRILIS IN THE SIX SEVENTH-GRADE ARITHMETIC TEXTBOOKS

\begin{tabular}{|c|c|c|c|c|c|c|c|}
\hline & Book & $I$ & II & III & IV & $\mathbf{v}$ & $v I$ \\
\hline Judge & $A$ & 2 & 1 & 3 & 3 & 2 & 1 \\
\hline Judge & B & 2 & 2 & 2 & 3 & $\boldsymbol{Z}$ & 2 \\
\hline Judge & C & 2 & 2 & 2 & 3 & 2 & 2 \\
\hline Judge & $D$ & 3 & 2 & 3 & 3 & 2 & 2 \\
\hline Judge & $\mathbf{E}$ & 3 & 2 & 3 & 3 & 2 & 2 \\
\hline Averag & & 2.4 & 1.8 & 2.6 & 3.0 & 2.0 & 1.8 \\
\hline Rank & & 4 & 1휴 & 5 & 6 & 3 & 1竞 \\
\hline
\end{tabular}

The interesting thing is how little attention is given to drill distribution in most of the textbooks. Book IV is partioularly poor in this respect: the drills appear to be put in at intervals and in amounts convenient in the arrangement of the book rather than as related to the learning process. 
XVII. Extent to which the amount of drill is propontionate to difficulty of operation in the aix textbooks. I'he ratings of the judges on this point follow:

RATINGS ON THE EXTENT TO WHICH DRIII IS PROPORIIONATE TO DIFFICULTY OF OPERATION IN THE SIX TEXTBUOKS

(1 = Superior, 2 = Average, 3 = Inferior) Book I II III IV V VI

Judge A

31

3

3

21

Judge B

22

2

2

2

2

Judge $C$

2

2

2

3

2

2

Judge D

31

3

3

2

1

Judge $\mathrm{E}$

3

1

3

3

2

1

$\begin{array}{lllllll}\text { Average } & 2.6 & 1.4 & 2.6 & 2.8 & 2.0 & 1.4\end{array}$

Rank

4t 2t 4 娄 6

3

1

XVIII. Use of "mixed" rether than "1solated" drills in the six seventh-grade arithmetic textbooks.

Opon careful analysis the witer concluded that Book VI is the only one making oven average use of mixed drills. ithe percentage of drill materials that were "mixed" as opposed to "isolated" in the a1x books were: Book I, 25\%; Book II, 30.1\%; Book III, 0.0\%; Book IV, 3.5\%; Book V, 0.0\%; and Book VI, 38.8\%. That the procedures followed in these books 1s not in keoping with the experimental data in the field has been show in Chapter III. 
The ratings of the judges follow:

RATINGS ON THE USE OF "MIXED" RATHER THAN

"ISOLATED" DRILLS IN SIX ARITHMETIC TEXTBOOKS

$$
\begin{aligned}
& \text { (1 - superior, } 2=\text { Average, } 3=\text { Inferior) } \\
& \text { Book I II III IV V V VI }
\end{aligned}
$$

$\begin{array}{lcccccc}\text { Judge A } & 2 & 2 & 3 & 3 & 3 & 1 \\ \text { Judge B } & 3 & 2 & 3 & 3 & 3 & 2 \\ \text { Judge C } & 2 & 2 & 3 & 3 & 3 & 2 \\ \text { Judge D } & 2 & 2 & 2 & 3 & 3 & 2 \\ \text { Judge E } & 2 & 2 & 3 & 3 & 2 & 2 \\ \text { Average } & 2.2 & 2.0 & 2.8 & 3.0 & 2.8 & 2.8 \\ \text { Rank } & 3 & 2 & 4 \text { t } & 6 & 4 \text { t } & 1\end{array}$

XIX. Inventors tests in the $81 x$ seventh-grade arithmet10 textbooks.

Whe writer examined each of the textbooks to find out how many test altuations were devoted to determining what the child kmow as an inventory of what he should be taught. While it would have been dealrable to know how carefully those tests had been ralldated, how rellable they were, and exactly what the anthors wished to find out, most of these data were not ava1lablo. A rough clessification of the fields covered by the inventory tests and the number of test situations provided in each of the six books 1s given below: 
NUMBERS OF INVENTORY TEST SITUATIONS PROVIDED IN SIX ARITHMETIC TEXTBOOKS

Book I II III IV V VI

Decima 18

4

1

Fractions

2

1

Fundamentals

8

1

Percentage

1

1

No. Survey lests $15 \quad 0 \quad 0010004$

'that adequacy of aurvey testing is not

determined by number of test situations alone is show by the ratings of the juages. They rate Books I and VI as superior, Book I having 15 survey tosts and Book VI having only 4. 'the equality with whioh the aurvey tests of the two books are rated 18 due to the fact that the tests are mased in Book VI while they are widely distributed in Book $I$.

RATINGS ON ADEQUACY OF INVENTURY TESTS IN THE SIX ARITHMETIC TEXTBOOKS

( 1 = super1or, $2=$ Average, $3=$ Infertor) Book I II III IV $V$ VI

Judge A

13

$3 \quad 3 \quad 3$

1

Juage $B$

13

3

33

1

Judie C

1

3

3

3

3

1

Juäe D

32

3

3

2

2

Judge $\mathbf{E}$

3

2

3

3

2

2

Average

1.8

2.6

3.0

3.0

2.6

1.6

Rank

2

3함 5홍

5t 3t

1 
XX. Provisions for diagnostic testing in the six soventhgrade arithmotic textbooks.

In the opinion of the judges, Book $\mathrm{V}$ 1s the only one of the six texts that is superior in its provisions for diagnostic testing. Their ratings follow:

RATINGS ON PROVISIONS FUR DIAGNOSTIC TESTING IN SIX SEVENTH-GRADE ARITHMATIC TEXTBOOKS

$$
\text { ( } 1 \text { = Superior, } 2 \text { = Average, } 3 \text { = Inferior) }
$$

Book I II III IV V VI

$\begin{array}{lcccccc}\text { Judge A } & 2 & 2 & 3 & 3 & 1 & 2 \\ \text { Judge B } & 2 & 2 & 3 & 3 & 1 & 2 \\ \text { Judge C } & 2 & 2 & 3 & 3 & 1 & 2 \\ \text { Judge D } & 3 & 1 & 2 & 3 & 1 & 1 \\ \text { Judge E } & 3 & 1 & 3 & 3 & 1 & 1 \\ \text { Average } & 2.4 & 1.6 & 2.8 & 3.0 & 1.0 & 1.6 \\ \text { Rank } & 4 & 2 & 5 & 6 & 1 & 2 \frac{1}{6}\end{array}$

The ratings do not reveal the entire situation with respect to diagnostic testing since two of the books, Numbers III and IV, make no provision whatsoover for diagnosing the student's difficultios. The number of sots of diagnostic tests in each of the six books is shown below:

NUMBERS OF SETS, OR GRUUPS, OF DIAGNOSTIC TEST ITEMS IN THE SIX SEVENI'H-GRADE ARITHMETIC TEXTBOOKS

$$
\text { Book I II III IV V VI }
$$

Areas

Decimals

Fractions 
Interest 1

Percentage 12

1 4

I'otal No. Hests 440

0 10

6

XXI. Provisions for romodial testing in the six soventhgrade arithmetic textbooks.

Anelyses of the books showed that they supplied sots or groups of remedial test items on various subjects as follows:

NUMBERS OF REMEDIAL TESTS IN THE SLX SEVENTHGRADE ARITHMETIC TEXTBOOKS Book I II III IV V VI

Docima is

6

4

2

3

Fractions

5

74

6

3

Fundementals

6

2

9

7

8

Percentage

6

7

5

Vocabulary

No.

Remodial

17

$15 \quad 17$

1

23

19

'the ratings of the judges on provisions for

remedial testing follow:

RATINGS ON PROVISIONS FOR REMEDIAL TESTING IN THE SIX SEVENTH-GRADE ARITHMETIC TEXTS

( 1 = Superior, 2 = Average, 3 = Inferior) Book I II III IV V VI

$\begin{array}{lcccccc}\text { Judge A } & 3 & 3 & 3 & 3 & 3 & 3 \\ \text { Judge B } & 3 & 3 & 3 & 3 & 3 & 3 \\ \text { Judge C } & 3 & 3 & 3 & 3 & 3 & 3 \\ \text { Judge D } & 2 & 3 & 3 & 3 & 1 & 3 \\ \text { Judge E } & 3 & 3 & 3 & 3 & 2 & 3 \\ \text { Average } & 2.8 & 3.0 & 3.0 & 3.0 & 2.4 & 3.0 \\ \text { Rank } & 2 & 4 \frac{1}{2} & 4 \frac{1}{8} & 4 \frac{1}{2} & 1 & 4 \frac{1}{2}\end{array}$


It is highly significant that, in the opinion of the judges, all the textbooks are definitely inferior in their provisions for remedial testing. Even a casual examination of the books reveris these inadequacies. XXII. Use of both "short-answer" objective tests and tests calling for sustained application in the six seventhgrade arithmotic textbooks.

since the testing program of the textbooks, speaking generaliy, are so infertor, ratings on this point would have little value. The witer would rate them all as inferior with nothing to choose betwoen the six, giving them all the rank of 3t. As pointed out in Chapter III, modern educational thought stipulates thet testing procedures must be integral parts of the textbooks, eithor incorporated in the same covers or supplied separately. It is disconcerting to note that of these six, supposediy modern textbooks, not one has an adequate testing program. Book I has a fow good vooabulary tests; the tests in Book II, are generally poox; Book III makes some good use of practice tests; Book IV makes use of scarcely any testing procedures at all; Book V, while testing better than any of the others, is still far from satisfactory; and Book VI is cortainly far from superior in its use of testing tochn1ques. Ihe writers of these textbooks are far from attainment of modern educational principles in their handling of testing procedures. 
XXIII. Provisions for individual differences in the six soventh-grade arithmet ic textbooks.

Book I makes little or no provision for various levels of ablitty. Book II has carefully provided for Individual differences through sets of special exercises and reports for the faster pup1ls. Book III has given fairly adequate attention to the problem of individual difforences through grading the work in order of diffleulty and varying the amounts for three lovels of ability. Book IV makes no apparent provision for individual differences. Book $\nabla$ stars extra problems and exercises for the faster pupils. An outstanding feature of Book VI is its provision for Individual differences. Many examples and problems are given for the faster pupils. Difficultios are pointed out and along with these are given "holphints" with number of pages suggested where holp may be secured for partioular types of difficulty. In the opinion of the writer, Book VI 1s superior in 1ts prom visions for individual differenoes, though there is st111 room for 1mprovement. Book IV and Book I are definitely inferior and Books II and III are about average in their provisions for individual differeneos. The rankings of the books with respect to this fect we would be, in the opinion of the rriter: Book VI, Book II, Book III, Book V, Book I and Book IV. I'here is st11l much to be dono before any of these books meets the standards of modern educational and psychological thought. 
XXIV. "Onit" trpe of organization in the six seventiregrade arithmotic textbooks.

Unfortunately, units of work, such as those recommended by outstanding curriculum workers such as Draper, Caswell, and Campbell, are not found in the six books.

In all, there are seventy-five so-called units in the six books. Of these, only one ("irransportation and Communication", Book VI) approaches closely to the requiremonts of a good unit. Its good features are:

1. Bxcellent 1llustrative material and piotures to holp tho ohild visualize actual life situations in the flelds of transportation and communication.

2. Each problem is concerned with date that are recent, rich, and raried in scope.

3. The problems are technical, yet understandablo to aeventh-grade chilaren.

4. It 1s organized so that the pupil acquaints himself With those major flelds of human achievement.

5. It has general social value in famlliarizing the child with the social necessity of travel by land, sea, and air, and with the still closer social contacts of the radio, telegraph, telephone, and ma1ls.

6 . In the opinion of the writer it leads to other worthwhile activities as well as to mastery of arithmetio. 
7. It contains a wealth of accurate information. Its undesirable features are:

1. A lack of integration with other sehool subjects. With the exception of an historical reference to Morse's first telophone mossage in 1884 (P. 9), the un1t 1s roid of integration.

2. Verg littlo bodily activity is provided for.

3. Indiridual differenees recelve no consideration.

4. It does not supply references for finding the needed materials and information.

5. It is not sufficientiy comprehensive for a serenthgrade group.

In the opinion of the witer, Book VI would rank first of the six in type of organization, being about average as regards what a modern seventh-grade arithmetic textbook should be 11ke. 'the others are quite definitely inferior in organization, judging from the standards of modern educational thought as outlined in Chapter III.

XXV. Integration of arithmet1c Fith other school subjects and with rocational fields in the $81 x$ textbooks.

In examining for integration, as derined in Chapter III, each problem in each of the books was examined to determine the fleld or fields from which 1llustrative materials were dram. 'these were checked and tabulated. Illustrations of the mothods by which 
integration 1s secured in the six textbooks are given in Appondix $B$.

Neodless to say, integration in all the books centers about the grocery store-how much will so many things cost? How much change will one get back?, etc. Throughout, there 1s apparent disregard for the activities of the student, elther as a child or as an adult. One is led to wonder how tho authors and publishors oan justify the treatment of aritbmetic as an ond in itself when it offers such excellent opportunitios for acqualnting the child with rocationaland adult-activities. Examination of the books shows that most rocational fields are neglected completely in the six books.

The Inadequacies of integrative work in the textbooks are almost too obvious from the data to need - laboration. Iho miter rates all the texts as inferior In integration with littlo or nothing to choose betwoen the six.

XXVI. Balonce betreen adult-and ohild interests in the six seventh-grade arithmet 10 textbooks.

Considerable information on the above point is found under number VI, above. It wes found that only Book II had used child interests to the exclusion of others in 1ts verbal problems. In the opinion of the witer, the books rank, with respect to balanoe of 
interest, exactiy as they are ranked in number VI, above: Book II, Book VI, Book III, Book V, Book I, and Book IV. 'these ranking are, of course, highly subjective and not overly valuable, considering that the five judges rated only one of the books (Number II) as being superior in its provision for motivation through appeal to ohllahood interests. XXVII. Revier of fundamentals, introduction of the algebraio formula, and attontion to intuitive geometry in the s1x seventh-grade arithmetic textbooks.

How adequately the six books treated the threo points given above was difficult to determino. the judges were agreed in classing Book IV as definitely Inferior but did not agree that any of the books was superior. In fact, they refused to give ratings on the above point beyond the generalizations given. In the opinion of the writer, Book IV should be rated as inferlor with the others recelving average ratings. It is quite obvious that the books as a whole do not conform to modern educational thought as given in Chapter III.

XXVIII. Suitability of the mechanical features of the six seventh-grade arithmetic textbooks.

In checking the mechanical features of the books the miter used the specifications given under No. XXVIII in Chapter III. Date on the mechanical 
features of the books are given below:

MECHANICAL FEATURES OF THE SIX SEVENTH-GRADE ARITHMET IC TEXTBOOKS

$\begin{array}{lrrrrrr}\text { Book } & \text { I } & \text { II } & \text { III } & \text { IV } & \text { V } & \text { VI } \\ \text { Length of page* } & 185 & 188 & 184 & 200 & 185 & 179 \\ \text { Width of page* } & 125 & 126 & 126 & 133 & 126 & 125 \\ \text { No. of pages } & 48 & 280 & 314 & 382 & 364 & 258 \\ \text { Serred binding } & \text { Yes } & & \text { Yes } & & & \\ \text { Staple bound } & & \text { Yes } & & \text { Yes } & \text { Yes } & \text { Yes } \\ \text { Longth of line* } & 88 & 86 & 86 & 85 & 88 & 89 \\ \text { Lines fine print } & 165 & 0 & 0 & 534 & 33 & 53 \\ \text { Protractors } & \text { Yes } & \text { No } & \text { Yes } & \text { NO } & \text { Yes } & \text { NO } \\ \quad \text { *Mllimeters } & & & & & & \end{array}$

The witer's ratings on mochanical foatures follow, using the standards previously ofted:

RATINGS ON MECHANICAL FEATURES OF SIX SEVENMHGRADE ARITHMETIC TEXTBOOKS

(1 = super1or, 2 = Average, 3 = Inferior)

\begin{tabular}{|c|c|c|c|c|c|c|}
\hline Book & $I$ & II & III & IV & V & VI \\
\hline Binding & 1 & 2 & 1 & 2 & 2 & 2 \\
\hline Paper & 1 & 1 & 1 & 1 & 1 & 1 \\
\hline size type & 2 & 1 & 1 & 3 & 2 & 2 \\
\hline Iongth of line & 1 & 1 & 1 & 1 & 1 & 1 \\
\hline Pages uncrowded & 1 & 1 & 2 & 3 & 2 & 2 \\
\hline Illustrations & 1 & 1 & 1 & 3 & 2 & 2 \\
\hline Life int. of Ills. & 3 & $\mathbf{2}$ & 1 & 2 & 1 & $\mathbf{3}$ \\
\hline Protractor & 1 & 3 & 1 & 3 & 1 & 3 \\
\hline Average & 1.3 & 1.3 & 1.1 & 2.3 & 1.5 & 2.0 \\
\hline Rank & $2 \frac{1}{2}$ & 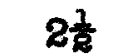 & 1 & 6 & 4 & 5 \\
\hline
\end{tabular}


XXIX. Summary:

A surmary of the ratings of the $1 x$ books analyzed in Chapter IV follows:

PABIE 29

SUMMARY OF THE RATINGS OF THE SIX SEVENTHGRADE ARITHMETIC TEXTBOOKS ANALYZED IN CHAPTER IV ACCORDING TO THE CRITERIA ESTABIISHED IN CHAPTER III AS THE DESIRED CHARACTERISTICS OF MODERN TEXTBOOKS AT THIS LEVEL

(1 = Superior, 2 = Average, 3 = Infertor. Ithe ratings basod on the individual judgment of the writer are marked with an asterlok. 'those not so marked are averages of the ratings of the three judges. .)

Book I II III IV V VI

I. General Philosophical Background*

$\begin{array}{llllll}3.0 & 1.0 & 3.0 & 3.0 & 1.0 & 2.0\end{array}$

II. Character and C1ti-

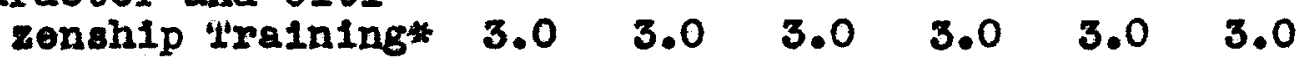

III. Vocabulary

$\begin{array}{llllll}2.3 & 1.3 & 2.0 & 3.0 & 2.3 & 1.3\end{array}$

IV. Sontenco Strueturo

$2.0 \quad 1.3$

2.0

$3.0 \quad 1.3 \quad 1.3$

V. Defining New irerms in Context

$2.0 \quad 1.3$

2.0

3.0

1.3

1.3

VI. ChIld Interest

2.3

1.0

1.7

$2.7 \quad 1.7 \quad 1.7$

VII. Explanations Addressed

$$
\text { to child }
$$

2.0

$1.3 \quad 1.7$

3.0

1.7

1.0

VIII. Illustrations Visvalize Lifo

$3.0 \quad 1.7 \quad 1.3$

2.3

1.3

2.0

IX. Games and Contests

1.7

3.0

3.0

3.0

2.0

3.0

x. Problom solving*

1.0

1.0

1.0

1.0

$1.0 \quad 1.0$

$X I$. Thrift and Investmonts

$\begin{array}{llllll}2.3 & 1.0 & 2.3 & 2.0 & 1.3 & 1.3\end{array}$

XII. Conoreteness

$\begin{array}{llllll}2.3 & 1.3 & 2.3 & 2.3 & 2.0 & 1.0\end{array}$

XIII. Graphs and Formulas

$\begin{array}{llllll}2.3 & 1.0 & 1.3 & 2.3 & 2.0 & 1.3\end{array}$

XIV. Reasoning Problems and Iffo 
I II III IV $\quad \boldsymbol{V}$ VI

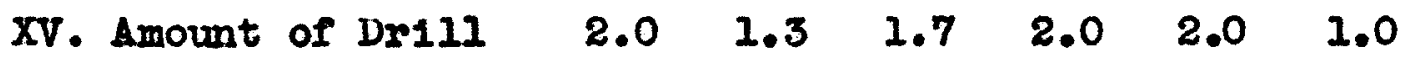

$\begin{array}{lllllll}\text { XVI. Drill Distribution } 2.0 & 1.7 & 2.3 & 3.0 & 2.0 & 1.7\end{array}$

XVII. Dr1II Proportion-

$\begin{array}{lllllll}\text { ate to Difficulty } & 2.3 & 1.7 & 2.3 & 2.7 & 2.0 & 1.7\end{array}$

$\begin{array}{lllllll}\text { XVIII. Mixed Drill. } & 2.3 & 2.0 & 3.0 & 3.0 & 3.0 & 1.7\end{array}$

XIX. Inventory l'ests $\quad \begin{array}{llllll}1.0 & 3.0 & 3.0 & 3.0 & 3.0 & 1.0\end{array}$

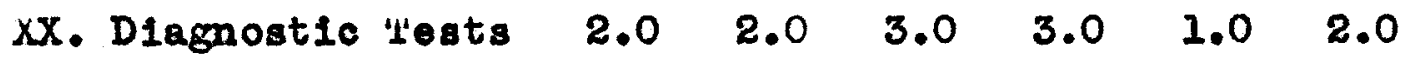

XXI. Remedial 'lests $3.0 \quad 3.0 \quad 3.0 \quad 3.0 \quad 3.0 \quad 3.0$

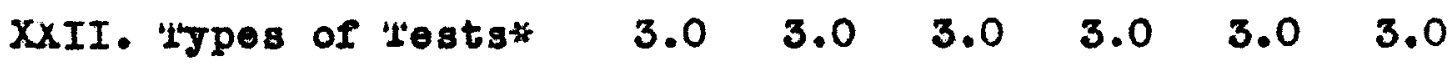

XXIII. Indiridual

$\begin{array}{lllllll}\text { Differences* } & 3.0 & 2.0 & 2.0 & 3.0 & 2.5 & 1.0\end{array}$

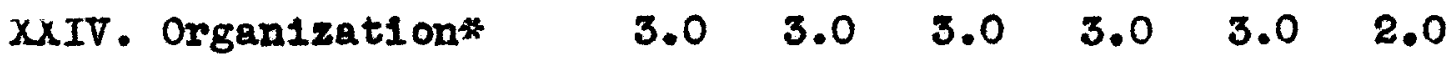

XXV. Integration* $\quad 3.0 \quad 3.0 \quad 3.0 \quad 3.0 \quad 3.0 \quad 3.0$

XXVI. Balance of ChIld-

and Adult Interests*

$\begin{array}{llllll}2.3 & 1.0 & 1.7 & 2.7 & 1.7 & 1.7\end{array}$

XXVII. Fundamentals, Alg-
ebra and Geometry* $2.0 \quad 2.0 \quad 2.0$

$\begin{array}{lllllll}X X V I I I . M e c h a n i e s & 1.3 & 1.3 & 1.1 & 2.3 & 1.5 & 2.0\end{array}$

$\begin{array}{lllllll}\text { Average Rating } & 2.5 & 1.8 & 2.3 & 2.7 & 2.0 & 1.8\end{array}$

$\begin{array}{lllllll}\text { Rank } & 5 & 1 \text { t } & 4 & 6 & 3 & 1 \frac{1}{2}\end{array}$

The averages of the ratings as show

above are in strict harmony with the opinions of the judges as to the order or merit of the books, taken as a whole, with the possible exception of some slight preference shown for Book II as against Book VI. There was no disagreement as to the ranking of the other books. They were almost vehoment in saying that Book IV was very definitely 
inferior to the others.

While the averages of the ratings leave much to be desired in the books, greater weaknesses are show by examination of the ratings on individual characteristics shown as desirable in terms of modern educational and prychological thought. the books are woakest in: Prov1sions for charactor and citizenshlp training, Tests, Organization, Integration, and Motivation. In these respects it might be said with complete fustification that the texts are modern only in date of publication.

The textbooks are best in: Provisions for problem solving, Mochanios, Amount of drill, Ose of graphs and formulas, Addressing explanations to the child rather than to the teacher, Sentence structure, and Defining new terms in context as they are introduced.

In substance, it may be said that there is an unfortunate lag betwoen the modern seventh-grade arithmotio textbook and what modern educational 11terature says it should be. Recommendations as to how much of this yo obviated are given in Chapter $v$. 


\title{
CHAPTER V
}

\author{
SUMMARY AND RECOMMENDATIONS
}

It was pointed out in Chapter I that the rapid growth of the junior high school movement has brought to the fore the problem of ourriculum reorganization and construction to moet the demands of changes in odueational thought regarding oducation at this level. It was shown that there have been marked changes in curricula and textbooks and that the textbook is, not only an integral part of the curriculum, but, next to the teacher, the most important part.

In Chapter II 1t was show: (1) what the velue of a texbbook as a teaching device has little to do with Its adoption; (2) 'that the score-card mothod must bo supplomented by more painstaking analyses than are customary in most school systems; and (3) what the production of a modern textbook is so important and complicated a task that it cannot be ontrusted to publishors alone, or to authors alone: It should be the cooperativie undertaking of authors, school men, and publishors. If this cooperation is to be secured school men must set up more definite and more searching requiremonts for textbooks and must apply them to the textbooks they select. Whe major portion of the present study is 
devoted to determining what those standards should be, in terms of modern educational thought, and in measuring how adequately six seventh-grado arithmotio textbooks published in 1934 and 1935 meot those requirements.

Chapter III 1s an attempt to bring order out of a mass of educational and psychological literature as to what the modern seventh-grade arithmetic textbook hould be 11ke. I'hese desired characteristies are prosented under twenty-eight hoadings in Chapter III, c1tation being made to the ilterature whorever possible. the desiderata may be grouped, roughly, a follows:

Goneral phllosophioal background, No. I Character and citizenship training, No. II

Difficulty, Nos. III, IV and $\mathrm{V}$

Motivation, Nos. VI, VII, VIII and Ix

subject matter, Nos. $X, X I, X I I I, X I V, X X V I$, and XXVII Mothod, No. XII

Drill, Nos. XV, XVI, XVII and XVIII

Iests, Nos. XIX, XX, XXI and XXII

Individual differences, No. XXIII

Organization, NO. XXIV

Integration, No. XXV

Mechanios, No. XXVIII, a to $h$, inclusive

While exact specifications for certain of the points discussed under these headings in Chapter III are 
vague and mast be inforred rather than taken directly from the literature, it is surprising, in the opinion of the witer, that there is such a close agreoment oonsldering the diverse fields from whioh much of the Iiterature comes and the fact that many of the witers discussed these problems rather ineidentally while dealing with considerably different mojor problems. what they do not form a perfect or complete outline of what the moderm seventh-grade arithmetic toxtbook should be like, but one that is markedis superfor to the rather haphazard methods employed by most schoal systoms in analyzing and solocting textbooks is the contention of the witor. That such eriteria can bo used by carefully trained and experlenced teachers in ovaluating textbooks for use in thoir olasses is demonstrated in Chapter IV.

The twonty-oight points set down in Chapter III as desiderata of the modern seventh-grade arithmet1e textbook were formulated as instmuctions to five teachers of soventh-grade arithmotic in the Ioussvillo public schools (Appondix C). With these instructions before them they rated the six textbooks published in the jears 1934 and 1935 as superior, average or inferior on each point. 'these ratings, together with more detalled analyses of Diffioulty, Integxation, Oxganization, Subject Matter, Drills, and Mochanios by the 
witer Individually form the basis of Chapter IV.

How adequately the six books meet the spoe-

ifications for the modern seventh-grado arithmotic toxtbook la1d down in Chapter III may be seon from the table given below. The ratings of the individual judges, and in some instances the opinions of the writer alone, or the ratings of the judges plus additional analysis by the witer, are oombined to give average oraluations on the twolve major points given below. these are taken from the more detalled ovaluations given in the Summary of Chapter IV:

EVALUATIONS OF SIX SEVENIH-GRADE ARITHMETIC TEXTBOOKS IN TERMS OF CR TTERIA SET DOWN IN MODERY EDUCATIONAL AND PSYCHOLOGICAL LTTERAT URE

$$
\text { (1 - superior, } 2 \text { - Average, } 3 \text { = Inforior) }
$$

$I$ II III IV V VI

I. General Philosophical

Background

$\begin{array}{llllll}3.0 & 1.0 & 3.0 & 3.0 & 1.0 & 2.0\end{array}$

II. Provisions for Iraining in Character and C1tironship

$\begin{array}{llllll}3.0 & 3.0 & 3.0 & 3.0 & 3.0 & 3.0\end{array}$

III. Diffioulty

$\begin{array}{llllll}2.1 & 1.3 & 2.0 & 3.0 & 1.6 & 1.3\end{array}$

IV. Mot1vat1on

$\begin{array}{llllll}2.3 & 1.8 & 1.9 & 2.8 & 1.4 & 1.9\end{array}$

V. subject matter

$\begin{array}{llllll}2.3 & 1.2 & 1.9 & 2.3 & 1.5 & 1.7\end{array}$

VI. Mothod

$\begin{array}{llllll}2.3 & 1.3 & 2.3 & 2.3 & 2.0 & 1.0\end{array}$

VII. Drill

$\begin{array}{llllll}2.3 & 1.7 & 2.3 & 2.7 & 2.3 & 1.8\end{array}$

VIII. Testing

$\begin{array}{llllll}2.3 & 2.8 & 3.0 & 3.0 & 2.5 & 2.3\end{array}$

IX. Provisions for Individual D1fferences

$\begin{array}{llllll}3.0 & 2.0 & 2.0 & 3.0 & 2.5 & 1.0\end{array}$ 


\begin{tabular}{|c|c|c|c|c|c|c|c|}
\hline & & I & II & III & IV & $\mathbf{v}$ & VI \\
\hline $\mathrm{x}$. & Organ1zat1on; "Units" & 3.0 & 3.0 & 3.0 & 3.0 & 3.0 & 2.0 \\
\hline XI. & $\begin{array}{l}\text { Integration with } \\
\text { other subjects and } \\
\text { with vooations }\end{array}$ & 3.0 & 3.0 & 3.0 & 3.0 & 3.0 & 3.0 \\
\hline XII. & Mechrnics & 1.3 & 1.3 & 1.1 & 2.3 & 1.5 & 2.0 \\
\hline & Average Rating & 2.5 & 1.8 & 2.3 & 2.7 & 2.0 & 1.8 \\
\hline & Rank & 5 & 1意 & 4 & 6 & 3 & 1* \\
\hline
\end{tabular}

In general, it may be said that none of the books 1s sufficientiy moderm in terms of present-day educat1onal thought to serve the chlldren in seventh-grade arithmetic adequately. Furthermore, using all of the textbooks examined, or using parts from several of them, would not provide a satisfactory textbook in seventh-grade arithmotic.

\section{Spocifically, it may bo sald that:}

1. Only two of the textbooks are by authors who are juaged to have the desired philosophlcal baokgrounds for writing seventh-grade arithmetic textbooks. Modern oducational thought is that at loast throe fields should be represented in preparing a textbook for the seventh grade: (1) Academic education; The olassroom, and (3) the specific flold (Nathoematics, History, etc.) for which the book 18 intended. Only Books II and V are rated by the judges as moeting these requirements.

2. None of the books is at all modern with respect to treining in oltizenship and character. 'ther seem to have overlooked these all-important flelds entirely. 
3. Books II and VI are reasonably modern in their usage of terms within the range of comprehension of the children for whom they were intended. Ihey use reasonably easy sentences and paragraphs and define most new terms in context as they introduce them. whey are not entirely sat1sfactory, however, and leave a considerable amount to the teacher that an Inexperienced teacher could not do.

4. None of the books pays adequate attention to the task of motivating the child. 'there is considerable room for improvemont in relating arithmotic to the child's interests and activities, providing games and contests, etc. Book $V$ is best in this respect.

5. Only one of the books, wo. II, is reasonably modern in its selection of subject matter. Even this would have to be supplemented by the teacher to meet the requirements of modern educstionel thought.

6. Books II and VI are reasonably modern in thoir methods of instruction. 'they provide opportunitios for actual physical act181ty--measurements, for instance-and for practice in estimating, otc.

7. None of the books is satisfactory regarding provisions for drill. Books II and VI have about enough drill, none of the books distributes dr1lls properly, and none of them takes adequate account of the fact that "mixed" drill is much more effective than "1solated" dr111. 
8. None of the books tests adequately. Books I an VI are satiafactory in their provisions for inventory tosting. Book V has good diagnostic tests. None of the books makes adequate usage of remodial testing techniques, and none of the books gives due attention to various types of tests. Ihey seem to regard the "short-answer" test as the only type worthwhile, overlooking the advantages of providing test situations In which the child has to sustain attention at a task over a protracted period of time.

9. Book VI provides satisfactorily for individual differences. The others are elther average or infertor. Book VI is the only one that could be used satisfactorily with the varying degrees of abllity in the average seventh grade.

10. None of the books is organized around the "Onit" plan. 'the advantages outlined in Chapter III as incldent to "Un1t" organization would have to bo supplied by the teacher using any of the books-a highly Improbable thing.

11. i'he books are all infertor in the manner in which they integrate the work of arithmotic with that of other subjocts and with vocational fiolds. So far as these books are concerned, arithmetic is still an 1solated body of subject matter and the child is supposed to fill some compartment of his mind with isolated facts and techniques. 
12. None of the books is strictly satiafactory in mechan1cal features. 'type of binding is satisfactory in only two of them (NOs. I and III). S1ze of type is satisfactory in only Books II and III--I'the others use entirely too much fine print. 'the pages are unduly orowded in all but Books I and II. IIlustrations are satisfactory in only Book III. Books II, IV and VI do not provide the student with a protractor, a seoming necessity to the student of seventh-grado arithmetic.

\section{Recommendat1ons:}

At the completion of a study such as this It is quite reasonable to try to answer some of the questions which naturaliy ariso as to what can or should be done about the textbook situation in seventhgrade arithmetic in o ofty school system. since the textbooks now ava1zable do not measure up to modern oducational thought one of two coursos is indicated: (1) Discard the textbook ontirely and provide the chlld with stady sheets worked out by local committeex; or (2) supplement the best, or several of the best textbooks with materials designed to overcome the weakness and shortcomings show by analyses such as the present one. Nelther of these would be new to the Ioulsville schools since a committeo has already written a course of study, almost a text, for the 
underprivileged child and another for the ninth-grade general mathematics course.

Specifically it is recoumended that:

1. Before a seventh-grade arithmetic textbook is adopted for any school system there should be a thorough analysis of educational and psychological Iiterature to determine what leaders in the fleld think an arithmetic textbook for this level should be 11ke. Such an analysis should be kept up to date by reference to literature of later date than that available for examination at the time this study was made. With increased information from the wide varlety of flelds bearing directiy upon seventh-grade arithmet1c, there will be important changes in oducational concepts from time to time, though it is scarcely probable that these will be as revolutionary during the next twenty years as they have been during the past.

2. Analyses of several textbooks thought to best meot the requirements of educational thought should follow examination of the literature in a most rigorous manner before any textbook is adopted. those responsible for the selection of the text should guard against the dangers of "high-pressure" salesmanship frequently employed by textbook distributors. Painstaking analysis is the only way of avolding such dangers as it can scarceity be 
expeoted that textbook publishers w11l provide such analyses when submitting a textbook for consideration. As shown by the present study, this analysis should conslst of careful ratings plus more detalled analJsis of features such as sentence length, vocabulary difficulty, and mechanical foatures, otc.

3. Assuming that an adoption was to be made at the close of the 1935-36 school term for the following year, and with the data from this study avaliable, the following would be a desirable course of action:

a. Adopt elther Book II or Book VI, depending upon the preferences of the individuals making the adoption: whe difference between them is too slight to warrant a choice on other than prejudicial grounds.

b. Supply the teacher with specific directions on how to secure definite onds in the development of character and citizenship--Industry, Cooperation, Courtesy, Honest, Dependab1lity, In1tiative, Self-Control, Moral Courage, Loyalty, Reveronce for established Institutions, Holerance, Aosthotic Appreciation and Optimism. As pointed out in this study, results in this fleld are to be expected from definite training with respect to specific situations, and not by moralistic lecturing. the answers should be taken out of both Books II and VI in order that 
the child's work may be checked with a minimum of effort.

c. Supply the child with definitions of difficult words that he w111 moet in the text and with $81 \mathrm{~m}$ ple explanations of certain portions of the texts which are too difficult for seventh-grade children. since this is the task of very skilled workers in the field it cannot be left safely to the indiv1dual teacher in the school system.

d. Supplement the text with a wide variety of problems of strictly "ohild" interest. Provide the child with more deta11ed and simpler explanations addressed expressiy to him and not to the teacher. Propare 1llustrations of life activitios in relation to arithmotic as supplements to the textbook. Supply each class with a careful system of games and contests to be used for motivating activity in the rarious topios as they are studied.

- Provide supplementary materials calling for a wide variety of actual activity on the part of the child-actual measurements such as surveying on an elementary soale, solving problems connected with the school grounds, estimating and checking of estimates, otc.

f. Supplement the drills, using only those that meot the requirements of what good drills should be. Developments in this field will have to be followed 
through investigations as they appear in current Iiterature.

8. 'the entire matter of testing should be gone into carefuliz and the textbook supplemonted. In vior of the advances made in this fleld during the past ten jears or so, there is no excuse for the inadequacies found in the books examined. The teacher should be provided with adequate testing materials, particularly of a diagnostic and romedial nature and directions for their use should be so complete that the teacher cannot make mistakes.

h. More attention should be given to provisions for individual differenoos. these aro not satisfactory in the textbooks examined. In terms of modern educational thought, the school is confronted, not only with the problem of varying the amount of work to sult the peed of learning of individual chilaren, but of adapting the type of arithmetic to be learned to what the child is able to learn, and how he will be able to use what ho does learn.

1. Experfenced teachers in this fleld could organize the materials of the textbook on a "Unit" basls. Whe advantages of this type of organization justify such a procedure.

f. Teachers and pupils should be provided with detalled information as to how arithmetic is used in other 
school subjects and in various vocational flelds. Ontil such time as textbooks in this field make such provisions it is the task of the local school system to provide them.

k. Tho child should bo provided with a protractor whether elther Books II or VI is adopted. These are not expensive and the amount of time they save is ample justification for their inclusion with the seventh-grade arithmetic textbook. 
APPENDIX A

EXCERPTS FROM THE SIX BOOKS

CHOSEN FOR VOCABULARY AINALYSIS

\section{Book I}

Per Cent

The expression per cent is an abbreviation

for per centum. We usually call per cent rate per cent or simply rate or fractional part. The number of which we find the per cent is called the base or whole. We must get clearly in mind the difference between per cent and percentage. Per cent is the rate; percentage is the result. P. 266

\section{Budget}

John and Mabel wished to go to housekeeping. They had to solve many problems which may come to each of you some day.

$$
\text { John's salary was } \$ 300.00 \text { a month; he had }
$$
trouble to make it last. The first year they had to give up some things they really needed because of unwise buying. The second year they planned each month's salary. Such a plan for one's income is called a budget. P. 376

\section{Banking}

Banks are the most important institutions in the business world. Without them modern business could not exist. Savings and investments are helped by banks. 
Many towns have school banks where the pup1ls may deposit their savings, but whether banks are large or small they all have certain things in common. P. 348 Discount

One of the commont practices in business is called discount. This is a percentage of the regular or list price that is taken off because the customer pays cash, or buys a quantity, or for some other reason. Trade discount is the allowance to the wholesaler or retaller to pay him for handling and selling the goods. P. 296

\section{Commission}

Many people make their living by selling goods for some other person. Often they are paid a certain per cent of the selling price of the goods that they sell. The money which they receive for selling the goods is called conmission.

Many people who sell butter, eggs, and produce of various kinds do business on commission. So do traveling salesmen, such as book agents. P. 321

Book II

Per Cent

Helen showed that the phrase per cent is usually expressed by a symbol. Some business houses often give a small per cent of discount for cash payment. Per cent is used by business men instead of the word hundredths. Per cent means by the hundred. Any fraction or decimal 
that is expressed as hundredths may be written as per cent. Per cent means hundredths. P. 70

\section{Budget}

A budget for the family expenses is planned in much the same way as the one on the next page. Before a family can make a plan for its expense it must know the approximate amount of income it will have. Jack's father and mother made a list of their probable income which appears below, such as--Fees, Salary, Dividends, Interest, Profits, and Gifts. P. 209

\section{Banking}

Banks lend a large part of the money deposited with them to business people of good standing who promise to repay the loan with interest. The interest on these loans provides a large share of the earnings of the bank, out of which salaries and other expenses are paid. P. 215

Discount

Mr. Brown allows all of his employees a special ten per cent discount on all articles they purchase at his store. Since Mary works there on Saturdays she is entitled to this special discount. During a dress sale Mary bought a dress which she liked. By buying this dress at the sale she received both the sale discount of ten per cent and the employee's discount. P. 258

Commission

Some people buy goods for other persons or firms on a comission basis. Their commission is calculated on the 
amount they pay for goods. An automobile salesman bought a used car for his friend. If the salesman charged three per cent for buying, how much was his commission if the car cost $\$ 800.00$ ? P. 269

\section{Book III}

Per Cent

You have learned that hundredths and per cent mean the same thing.

To change a decimal to per cent, move the decimal point two places to the right and annex the percent $\operatorname{sign}(\%)$.

To find what per cent one number is of another, alvide the number being compared by the number with which it is compared, carrying the division to hundredths, then write as per cent. P. 73

\section{Budgets}

Remember that a budget cannot be followed exactly, but it will help very much to determine how much money is to be spent. This chart shows the budget for two persons for one month based upon an income of $\$ 100$ per month.

There are many factors that enter into the making of budgets. No single budget can be planned to meet the requirements of all families. P. 110

Commission

Fred has a paper route. He is an agent for the publishers. The publishers send Fred fifty copies 
every Thesday. He sells all he can at five cents each and returns the rest to a local news dealer. He sends four cents to the publisher. He keeps one cent, which is his commission for selling the paper. P. 136

\section{Banking}

A bank is a business institution in which money may be deposited for safe-keeping.

When making your first deposit at a bank, you are given a pass book. You will be required to write your name on a signature card. In the pass book will be written the amount of the deposit.

A deposit may be in currency, silver, or gold, or It may be a check calling for money or some other person's deposit. P. 145

\section{Discount}

A merchant often finds that certain lines of goods have not sold so well as he had expected. The unsold goods will be out of fashion if kept over to another season. He needs the space for new goods and he needs the money that is tied up in his stock; so he offers the remaining articles at a lower price. These reductions in price are called discounts. P. 133

\section{Book IV}

\section{Percentage}

Percentage problems occur frequently in business transactions, particularly in those which require the computing of discounts, comissions, interest, and 
so on. It is also a common practice to express the relation between two numbers in per cent; for example, the relation of operating costs to sales, of advertising cost to sales, and so on. P. 121

Budgets

Every person who has any financial matters to handle should prepare a budget of expenses based on a definite or probable income. The person who works on a specifled salary, or the person who owns income-producing securities on which the income is definite, can plan his budget by month or by the year. P. 352

Commission

A commission merchant is one who transacts business for another party. The charge for this service is called comission. This commission is usually a certain percentage of the cost or selling price. A collection fee is a service charge made by the commission merchant when he makes the collections for goods sold on account. Pp. 146, 147

\section{Banking}

The banker accepts money on deposits from people who wish to avail themselves of banking facilities, either for checking purposes or for safe-keeping and interest income.

The banker, in turn, lends or invests certain portions of the deposits in his bank, and for these loans and investments he receives a higher rate of interest 
than he pays to depositors. P. 329

\section{Discount}

Trade discounts are deductions, according to the terms of the sale, from the list price of the goods sold. Discounts serve principally as a means of regulating prices. The list price is the price at which the goods are listed before the discounts are deducted. Net cost is the cost of the goods after the trade discounts are deducted. Pp. 129, 130

\section{Book V \\ Percentage}

In all parts of the world people now use per cents for many different purposes. You will find the language of percentage in newspapers and magazines, in almanacs, in reference books, in advertisements, and on posters. This fact will convince you that per cents are very helpful in describing and explaining the world's work.

\section{Percent means hundredths. P. 136 \\ Budgets}

One of the best ways to make sure that jou are spending your money wisely is to plan your expenditures ahead of time. Such a plan is known as a budget. This will vary according to the amount of your income, size of family, and the community in which you live. There are many good ways of organizing a family budget. One of the most common is to list under five main headings 
al1 money spent. P. 318

Commission

Farmers and fruit growers of ten ship their goods to the city, where they are sold by agents. Manufacturers send out traveling salesmen to take orders for their goods, and property owners employ real-estate agents to sell their property. Payments for such sales are usually made in terms of an agreed per cent of the money for which the goods are sold. This amount so paid is called a commission. P. 146

\section{Banking}

Mr. Arnold, the cashier of a savings-bank gave a talk on thrift to the seventh and elghth grade pupils of the Iincoln School. He emphasized the great importance of saving regularly, either from money recelved from parents or from money earned by the pupils.

He further explained that when a bank lends money it deducts the interest in advance. This interest is known as bank discounts. P. 217

\section{Discount}

During a dull business season merchants frequently reduce prices to attract more trade. During a January sale a merchant advertised overcoats for sale at a reduction of $20 \%$ of the marked price. Such a reduction is called a discount. You will find discounts advertised in most newspapers. Make a collection of advertisements and bring them to class with you. P. 144 
Book VI

Percentage

In percentage you need not learn any new mules for addition, subtraction, multiplication, or division. Since per cent means hundredths, you may solve any problem in percentage by using decimals. Percentage is like a new language in which the words "per cent" show the old Idea of hundredths. You should be thoroughly familiar with this new language. P. 54

Budgets

It is not a safe thing for a family to spend its income without some definite plan. Hence intelligent and forward-looking people try to make a budget and to follow it as closely as possible. A family budget is a definite plan for using the family income. It may cover a period of a week, or a month, or a year. P. 148

Comission

You have perhaps sold Christmas cards or magazines and recelved as your pay a definite part of the emount of your sales. Agents have called at your home selling brushes, books, vacuum cleaners, or other goods. Manufacturers, merchants, and farmers often depend on such agents to do business for them. These agents recelve a certain per cent of their sales as their commission. P. 113

Banking

Savings banks are used chiefly by people of 
small means who wish to place their money safely at interest instead of using it in active business.

Banks keep money at work. They take the money which the depositor leaves with them and lend it to the merchant, farmer, or other borrower who needs it for use and can give securlty for its repayment. The borrower pays the bank for the use of the money. P. 172

Discount

Wholesalers usualiy publish a catalogue which gives the list price for each article listed. This price is usually made great enough so that it is the maximum price that must be charged even if the price of material and labor should increase. In order to inform their customers about the actual prices at any time, wholesalers issue from time to time a list of discounts from these published list prices. P. 120 
APPENDIX B

ILLUSTRATIONS OF HOW INTEGRATION IS ATTEMPTED IN THE SIX BOOKS ANALYZED

I. EXAMPLES OF INTEGRATION IN BOOK I

$$
\begin{aligned}
& \text { a. Astronomy } \\
& \text { p. } 246
\end{aligned}
$$

Example. The visible stars have been arranged into six groups according to their apparent brightness. These groups are called "stars of the first magnitude", "stars of the second magnitude", etc. The following table shows the number of stars in each group:

First magnitude....20 Fourth magnitude... 425 Second magnitude...6 65 Fif th magnitude....1100 Third magnitude....190 Sixth magnitude....3200

Find the total number of stars visible to the unalded eye in all parts of the world. (P. 246)

b. Athletics pp. $56,57,133$

Example. A famous girl athlete made a world's record high jump of 5 feet, $33 / 16$ inches. If a junior high school girl could make a high jump of 3 feet, how much higher was the former girl's jump? (P. 56)

$$
\begin{aligned}
& \text { c. Aviation } \\
& \text { pp. 103, 104, } 235
\end{aligned}
$$

Example. Captain James Mollison flew from Ireland to New Brunswick, a distance of 2400 miles in $30 \frac{1}{4}$ hours. What was his speed per hour? (P. 104) 


$$
\begin{aligned}
& \text { d. Heal th } \\
& \text { p. } 81
\end{aligned}
$$

Example. The graph below from a junior high school in Los Angeles shows how corrective health work will remedy underwelght. See if you can explain it. (P. 8I)

$$
\begin{aligned}
& \text { e. Home Economics } \\
& \mathrm{pp} .50,51
\end{aligned}
$$

Example. A recipe required $4 \frac{1}{2}$ quarts of flour to make 6 loaves of bread. How much flour will be needed to make 18 loaves of bread? ( $P .50$ )

$$
\begin{aligned}
& \text { f. Physics } \\
& \text { pp. } 28,388
\end{aligned}
$$

Example. The speed of the earth is such that if a man, moving at the speed of the earth, started to tip his hat to a lady in New York he would be putting it on in Trenton, some 60 miles away, 4 seconds later. The speed of the earth is about $(1.5,150,15)$ miles per second. (P. 28)

$$
\begin{aligned}
& \text { g. Science } \\
& \text { pp. 83-85, } 87
\end{aligned}
$$

Example. On a Fahrenheit thermometer the freezing point of water is marked $32^{\circ}$, and the boiling point of water is marked $212^{\circ}$. How many degrees are there between the freezing point and the boiling point? (P. 83)

$$
\text { h. Spelling }
$$

Example. Ten members of a seventh-grade class had the following number of words right in a spelling 
test of 25 words: $20,18,24,17,25,19,20,18$, 24, 25. Find the average number of words right. (P. 88)

$$
\begin{aligned}
& \text { 1. Social studies } \\
& \mathrm{pp} .130,131
\end{aligned}
$$

Example. On a certain map of Rhode Island the mapmaker used a scale of 10 miles to the inch. If the greatest length of the state is 48 miles and the greatest width is 37 miles, how many large squares and how many small squares would you use on squared paper to represent each of the above distances? (P. 131)

$$
\text { j. Statistics }
$$

Example. The approximate death rate per 1000 persons in an Atlantic seaboard city is given below:

$$
\begin{array}{ll}
1925 \ldots \ldots 11.1 & 1929 \ldots \ldots 11.3 \\
1926 \ldots \ldots 11.7 & 1930 \ldots \ldots 10.8 \\
1927 \ldots \ldots 11.5 & 1931 \ldots \ldots 10.9 \\
1928 \ldots \ldots 11.5 & 1932 \ldots \ldots 10.3
\end{array}
$$

When was the rate highest? Lowest? ( .80 )

II. EXAMPLES OF INTEGRATION IN BOOK II.

$$
\begin{aligned}
& \text { 2. Economics } \\
& \text { pp. } 64,65,225
\end{aligned}
$$

Example. In 1930 the average price of milk was 14.0 cents a quart. Compare this price with the present price in your locality. What is the difference in price? (P. 64)

$$
\begin{aligned}
& \text { b. Forestry } \\
& \text { pp. 197-200 }
\end{aligned}
$$

Example. According to a recent report, the forest regions of the United States are divided into five 
districts as shown in the following table. What was the total original area of our forests?

What per cent of the original area ( 823 million acres)

is the remaining area? (444 mililon acres) (P. 197)

$$
\begin{aligned}
& \text { c. Health } \\
& \text { pp. } 52,236
\end{aligned}
$$

Example. Milk is one of the most valuable foods we have. Can you tell why?

In the United States each person consumes on the average 1.3 pints of milk per day. How many pints does he consume in a week? (P. 52)

$$
\begin{aligned}
& \text { d. Science } \\
& \text { pp. } 63,168,237
\end{aligned}
$$

Example. The normal rainfall in Mobile, Alabama, is 62.04 inches a year. What is the average monthly rainfall? (P. 63)

$$
\begin{aligned}
& \text { e. Physics } \\
& \text { p. } 182
\end{aligned}
$$

Example. Jack told Arthur that the pressure exerted on the sail by the wind was at that time about 3.5 pounds to each square foot of sail. What was the total pressure of the wind on the sail before the reer was taken in it? (P. 182)

$$
\begin{aligned}
& \text { f. Transportation } \\
& \text { pp. 3, 9, } 13
\end{aligned}
$$

Example. One of the largest and fastest ocean liners of the present time is 880 feet long. How many ships of the same length placed end to end would extend a mile? (P. 9) 
III. EXAMPLES OF INTEGRATION IN BOOK III.

$$
\begin{aligned}
& \text { a. Anthropology } \\
& \text { p. } 5,6
\end{aligned}
$$

Example. The greatest dinosaur was called the "Thunder Ilzard". It attained a length of 60 feet. The distance from home base to second base (126 feet) is how much more than the length of this dinosaur? (P. 6)

$$
\begin{aligned}
& \text { b. As tronomy } \\
& \text { pp. } 7-9
\end{aligned}
$$

Example. The distance from the sun to the earth is about $93,000,000$ miles. Light trevels about 186,000 miles per second. Find the time required for light to travel from the sun to the earth. (P.9)

$$
\begin{aligned}
& \text { c. Athletics } \\
& \text { pp. } 57,58,74,75
\end{aligned}
$$

Example. In $1929, G$. S. Simpson ran 100 jards in $93 / 5$ seconds. Find the average speed in feet per second. (P. 57)

$$
\begin{aligned}
& \text { d. Aviation } \\
& \text { pp. } 23-25
\end{aligned}
$$

Example. On Easter Sunday 1930, Mr. and Mrs. Charles Indbergh flew 2500 miles in about 14 hours. Find the average speed per hour. (P. 23)

$$
\begin{aligned}
& \text { e. Home Economics } \\
& \text { pp. 51-53, } 109
\end{aligned}
$$

Example. Old-fashioned Taffy
$1 \frac{1}{2}$ cups sugar
$\frac{1}{2}$ cup molasses
$1 \frac{1}{4}$ tablespoons vinegar
$3 / 4$ cup butter
To make 3 times as mach taffy, how much of each should be used? (P. 5I) 


$$
\begin{aligned}
& \text { f. Sclence } \\
& \text { pp. 54, 57, } 63
\end{aligned}
$$

Example. Find the cost of using an electric toaster for 15 minutes at the rate of $3 \frac{1}{2} \phi$ per hour. (P. 54) IV. EXAMPLES OF INTEGRATION IN BOOK IV.

$$
\begin{aligned}
& \text { a. Agricul ture } \\
& \text { pp. } 342,345
\end{aligned}
$$

Example. In 1930, according to the Federal census, the total number of persons engaged in agricultural work was $10,482,323$. The total population of the United states in 1930 was 122,775,046. What percent of the total population was engaged in agriculture? (P. 342)

$$
\begin{aligned}
& \text { b. Communication } \\
& \text { pp. } 310,315
\end{aligned}
$$

Example. There are now 17,857,000 telephones in the United states. If there are 125,000,000 people living in this country, there is one telephone for about how many persons? (P. 315)

$$
\begin{aligned}
& \text { c. Dairying } \\
& \text { pp. 349-352 }
\end{aligned}
$$

Example. The price pald for milk varies in proportion to the amount of butterfat in the milk content. The butterfat content of milk varies from $3 \%$ up to $5 \%$. In most localities $3.6 \%$ is considered standard. This is how much below the average? (P. 349)

$$
\begin{aligned}
& \text { d. Health } \\
& \text { pp. 27, 31, } 67
\end{aligned}
$$

Example. A certain European city has kept vital statistics since about the year 1500. These statistics 
show the following facts: In the 1500's the average length of life was 21 years; in the 1600's, 26 years; In the 1700's, 34 years; and in the 1800's, 40 years. The average length of Iife in the 1800 's was an increase of percent over the average length in the 1500's. (P. 31)

๑. Home Economics pp. $7,19,23$

Example. A punch recipe calls for 2 cups of water for each cup of fruit juice. How many cups of water are needed for 2 cups of fruit juice? 3 cups? (P. 23)

$$
\begin{aligned}
& \text { f. Sclence } \\
& \text { pp. 12, 31, 48 }
\end{aligned}
$$

Example. Rosebushes are sometimes dusted with a preparation consisting of 9 parts of dusting sulphur and 1 part of arsenate of lead. What is the ratio of the dusting sulphur to the arsenate of lead? (P. 3I)

V. EXAMPLES OF INTEGRATION IN BOOK V.

$$
\begin{aligned}
& \text { a. Agricul ture } \\
& \text { pp. } 42,43
\end{aligned}
$$

Example. Marle attended the Young People's Agricultural Institute and became interested in poultry raising. After a careful study of the possibilities of making some money by keeping poultry, she decided to enter the poultry business on April 1. During the first six months Marle's hens laid 954 eggs. At 25 cents a dozen, she figured that they were worth _ dollars. (P. 42) 


$$
\begin{aligned}
& \text { b. Athletics } \\
& \text { pp. Ill, } 117
\end{aligned}
$$

Example. In 1933 the metric system was substituted for the yardage system in most college athletics. Now one hears: "All out for the 200-meter dash", rather than, "All out for the 220-yard dash". What is the difference in distance between 200 meters and 220 yards. (P. 11I)

$$
\begin{array}{r}
\text { c. Civics } \\
\text { p. } 322
\end{array}
$$

Example. John received 18 votes for class president, Harry recelved 14, and Ellen 12. John was elected by a plurality of 4 votes. A plurality means the number of votes more than the next highest candidate received. How do you find John's plurality? (P. 322)

$$
\begin{aligned}
& \text { d. Communication } \\
& \text { pp. 48-51 }
\end{aligned}
$$

Example. During a recent year there were $6,741,788$ pounds of mall carried by alpplane. A pound of mall averages 40 letters. About how many letters were carried by air mall that year, assuming that all the air mail was letters? (P. 48)

$$
\text { e. Dairying }
$$

Example. Above is a photograph of April Pogus recentiy judged the prize Jersey milk cow in the United States. She was bred in Vermont. During the official test of a year's duration April Pogus produced 17,880 pounds of milk. Allowing 3 
pounds to a quart, how many quarts was that? how many gallons? (P. 269)

f. Forestry pp. 52,53

Example. Thirty-seven states in the United States appropriate money annualiy to protect their forest against fire. Is this about $1 / 2,2 / 3$, or $3 / 4$ of the total number of states? (P. 53)

$$
\begin{aligned}
& \text { g. Health } \\
& \text { pp. 309, 310, 312, } 313
\end{aligned}
$$

Example. In the United States there are approximately $3,000,000$ persons sick each day, on the average. If each day's illness represents a loss of $\$ 1.00$, what is the annual loss from illness? ( $P$. 310)

$$
\begin{aligned}
& \text { h. Home Economics } \\
& \text { pp. } 7,60,61,73,152,314,315
\end{aligned}
$$

Example. Helen is making a dress. The buttonholes on the dress are to be formed by loops of silk braid. Each loop requires $1 \frac{3}{4}$ inches of braid. There are 24 loops. She has a yard of braid. Will that bo enough? ( $P .73$ )

$$
\begin{aligned}
& \text { 1. Science } \\
& \text { pp. } 8,35,132
\end{aligned}
$$

Example. John wishes to use a mixture of water and alcohol in the radiator of his father's car. His science teacher advised him to $\mathrm{mix}$ alcohol and water so that the ratio of alcohol to water would be 3 to 5. Does that mean to use 3 parts of alcohol to 5 parts of water. How many quarts of water must John use if he used 
3 quarts of alcohol? (P. 8)

j. Social Studies

Example. From a geography textbook find the five longest rivers of the world and represent their lengths by a bar graph. (P. 6)

k. Surveying

p. 106

Example. Surveyors in the United States Geological Survey are not satisfied with their work if the error in the measurement is more than 1 part in $1,000,000$.

Complete: The error in a measurement may be decreased by using more finely graduated instruments, but it can never by wholly ? (P. 106)

VI. EXAMPLES OF INTEGRATION IN BOOK VI.

$$
\begin{aligned}
& \text { a. Communication } \\
& \text { pp. 9, } 10
\end{aligned}
$$

Example. There were 612 radio broadcasting stations in the United States in a recent year. These were so located geographically that .94 of the 125,000,000 people of the United States could have heard daytime programs if they had listened over radio sets. How many persons could have listened to the daytime radio programs? ( $P .10)$

$$
\begin{aligned}
& \text { b. Home Economics } \\
& \text { pp. } 4 I, 94
\end{aligned}
$$

Example. Mary's recipe for mint lemonade calls for the following: 
juice of 8 lemons

4 cups water

1늘 cups sugar

2 cups boiling water
12 mint sprigs

1 cup strawberry juice

1 cup raspberry juice

This reclpe is sufficient for 10 persons. Change the recipe to serve 5 persons; to serve 15 persons. (P. 4I)

$$
\begin{aligned}
& \text { c. Sclence } \\
& \text { pp. 84-86 }
\end{aligned}
$$

Example. Arthur has a 75-watt lamp in his room. How much per month will it cost for current if the lamp is lighted 60 hours a month and if electricity cost $7 \not l$ per K. W. H.? (P. 84)

$$
\begin{aligned}
& \text { d. Transportation } \\
& \text { pp. 1-4 }
\end{aligned}
$$

Example. The latest air liners have a cruising of 3 miles a minute. At this rate how long will it take one of these airplanes to fly from Pittsburgh to Indianapolis, a distance of 342 miles? (F. 4) 


\section{APPENDIX C}

INSTRUCTIONS USED BY THE JUDGES IN RATING SIX SEVENTH-GRADE ARITHMETIC TEXTBOOKS AS TO ADEQUACY WITH WHICH THEY CONFORM TO REQUIREMENTS OF MODERN EDUCATIONAL THOUGHT

(Those marked with an asterick were employed by the writer Individualiy and not by the other two judges.)

Directions:

Rate each of the six textbooks on each of the criteria given below as to whether 1t is (1) Superior, (2) Average, or (3) Inferior. Use the numbers 1, 2, and 3 to express your opinions. Your judgments will be more accurate if you will rank the books in order of merit before giving the ratings on each point. After you have rated the books, rank them in order of general merit as you see 1t. You may add other criteria, criticisms or suggestions in case you feel that the outline followed is not adequate.

*1. General philosophical background. What are the qualifications of the author or authors for the production of a textbook at this level and how well do they incorporate this philosophy into their texts.

*11. Provisions for character and citizenship training. How adequately do the textbooks provide a sound system of training in citizenship and character? How well does the text provide for training the child to be: Industrious, Cooperative, Courteous, 
Honest, Dependable, Resourceful, Even tempered, Courageous, Loyal, Reverent, Tolerant, Aesthet1cally appreciative, and Optimistic.

III. Vocabulary. Is the vocabulary of suitable difficulty for seventh-grade children?

IV. Sentences and Paragraphs. Are the sentences and paragraphs brief, simple and unifled to the extent required by seventh-grade children?

V. Definitions of new terms. How satisfactorily are new terms defined in context as they are introduced?

VI. Motivation Through Child Interests. Problems should involve data which is interesting to and a part of the child's experience. Problems about games, the store, school, home, and the like, are all a part of the child's dally expertence.

VII. Explanations. Should be addressed to the pupil rather than to the teacher.

VIII. Illustrative Material. Should visualize Iifo situations for the child.

IX. Games and Contests. Should be provided to help break the monotony of continuous arithmetical problems. They give the child a chance to displey his ability to think quickly.

$X$. Adequacy of Opportunity for Solving Problems.

XI. Thrift and Investment. How satisfactory are the provisions for teaching thrift and investment for 
everyday use--banking, Interest, savings, discount, budgets, etc.

XII. Concreteness of Problems. Problems should require actual measurements to be made, estimates given, etc.

XIII. Graphs and Formulas. The pupil should be trained for immediate and future use of graphs and formulas. He should learn to use them intelligently in his reading of newspapers, magazines and other current literature.

XIV. Reasoning Problems and Life Situations. To be of most value, problems should involve those things which make up the child's daily interests and activities.

XV. Amount of Drill. There should be enough drill to Iron out difficulties and make correct methods mechanical.

XVI. Distribution of Drills. Drills should be distributed in diminishing amounts and at more frequent intervals as the child progresses through the book. As the number of examples in the drills diminish, they should occur at more frequent intervals.

XVII. Drills Proportionate to Difficulty. More drill space should be allotted to those examples which involve a frequent difficulty rather than those of the same type but of lesser difficulty. 
be "mixed" in type rather than "isolated".

XIX. Inventory Tests. How adequately do the books test what the child knows in order that he may be taught what he does not know?

XX. Diagnostic Tests. How well are special difficulties tested for?

XXI. Remedial Tests. How adequately do the books provide special drill on the processes with which the child has particular difficulty?

*XXII. Types of Tests. Tests should be of the shortanswer type covering a wider range and of the type calling for sustained application.

*XXIII. Provisions for Individual Differences. How well do the books provide for differences in ability? *XXIV. "Unit" Type of Organization. How adequately are the books organized into "units"?

*XXV. Integration. How adequately is arithmetic integrated with other school subjects and with vocational fields?

*XXVI. Balance between Child- and Adult-Interests. XXVII. Review of Fundamentals, Introduction of the Algebraic Formula, Attention to Intuitive Geometry. How adequately are these handled?

*XXVIII. Mechanics:

A. Binding. Should be attractive and durable. B. Paper. Should be of good quality and weight. C. Size Type. Ten or eleven point. 
D. Length of Line. About eighty millimeters.

E. Pages. Should not be crowded.

F. Illustrations. Should be attractive.

G. Illustrations. Should help pupils visualize Iife situations.

H. Protractor. Should be provided.

XXIX. Rank the books in order of general merit keeping in mind all the factors you think should be considered in selecting a textbook for the seventh grade in Loulsvilie. 


\section{BIBLIOGRAPHY}

\section{HOW TO SELECT A TEXTBOOK}

1. Bagley, W. C., "The Textbook in American Education", School and Society, Volume XXXIII, March 14, 1931.

2. Barr, A. S., "Text Book Accounting", Elementary School Journal, XXIII, Pp. 127-135.

3. Benthack, Emil, "Standards for the Selection of Arithmetic Textbooks", Educational Research Record, University of Nebraska, February, 1929, pp. 85-90.

4. Betz, William, "Mathematics in Modern Education", National Council of Teachers of Mathematics, Eleventh Yearbook, Bureau of Publications, Teacher's College, Columbia Un1versity. New York, 1936, P. 93.

5. Bobbitt, Franklin, "How to Make a Curriculum", Houghton Mifflin Company, 1924, Pp. 282.

6. Breslich, E. R., "Reconstruction in Secondary School Mathematics", Ph. D. Thesis (Unpublished), University of Chicago, 1926.

7. Brueckner, I. J., "Diagnosis in Arithmetic", National Society for the Study of Education, Thirty-fourth Yearbook, Public School Publishing company, Bloomington, IIInois, 1935.

8. Buckingham, B. R., "The Scientific Development and Evaluation of Textbook Materials", Department of Superintendence, official Report, February 25 to March 2, 1933 , Pp. 159-166.

9. Buckingham, B. R., "The Social Value of Arithmetic", National Society for the Study of Education, Twentyninth Yearbook, Public School Publishing Company, Bloomington, IIlinois, Part II, 1930.

10. Burch, Mary C., "Determination of a Content of the Course in Literature of a Suitable Difficulty for Junior and Senior High School Students", Genetic Psychology Monographs, Volume IV, Numbers 2 and 3 , August-September, 1928 .

11. Burr, S. C., "Selection of Textbooks and the Use of Textbook Rating Scales", American School Board Journal, 79:130, August, 1929 . 
12. Butler, C. H., "Mastery of Certain Mathematical Concepts by Pupils at the Junior High School Level", The Mathematics Teacher, Volume XXV, Number 3, March, 1932, Pp. 117-172.

13. Caswell, H. I. and Campbell, D. S., "Curriculum Development, The Textbook", American Book Company, 1935, P. 45-47.

14. Charters, W. W., "Curriculum Construction", Macmillan Company, 1924, Pp. 344.

15. Cox, C. C., "The Early Mental Traits of Three Hundred Geniuses", Genetic Studies of Genius, Volume II, Stanford University Press, 1926.

16. Crofts, Thomas J., "A Scale for Arithmetic Texts", Chicago Schools Journal, June, 1929, Pp. 363-366.

17. Cubberley, E. S., State School Administration, Houghton Mifflin Company, 1927, Pp. 555-581.

18. Davis, D. R., "A Comparative Study of Text Books in Junior High School Mathematics", High School, 8:103114, February, 1931.

19. Dewey, John, "How We Think", D. C. Heath and Company, New York, 1930, P. 52.

20. Donovan, H. L, "How to Select Textbooks", Peabody Journal of Education, 2:1-11, September, 1924.

21. Draper, E. M. and Roberts, J. I., "Principles of American Secondary Education, Appleton-Century Company, New York, 1932.

22. Dunlap, J. W. and Kurtz, A. L., "Handbook of Statistical Monographs, Tables and Formulas", World Book Company, 1932, Formula 154.

23. Dunn, M. W., "Score Sheet for Judging Basic Textbooks", Curriculum Principles and Practices, Sanborn Company, 1929 , Pp. 581-603.

24. Fowlkes, J. C., "Evaluating School Textbooks", Silver Burdett Company, New York, 1923.

25. Franzen, R. H. and Knight, F. B., "Textbook Selection" Worwich and York, Baltimore, 1922.

26. Fuller, F. D., "Scientific Evaluation of Text Books", Houghton Miffilin Company, 1928. 
27. Grossnickle, F. E., "Concepts in Social Arithmetic for the Eighth Grade Leveln", Junior Educational Research, Volume XXX, Number 3, March, 1937.

28. Hall-Quest, A. I., "The Textbook", Macmillan Company, New York, 1918.

29. Harap, Henry, "Evaluation of Curricula and Texts", Review of Educational Research, January, 1931, Pp.43-45.

30. Hartshorne, Hugh and May, M. A., "Studies in Deceit", Studies in the Nature of Character, Book I, The Macmilian Company, 1931.

31. Herrlott, M. E., "Textbook Adoption and Evaluation", Procedures, Los Angeles Secondary School, Los Angeles Educational Research Bulletin, 10:2-5, October, 1930.

32. Hogan, Forrest $P_{.}$, "An Objective Appraisal in Eight Grade Arithmetic Textbooks," Master's Thesis, State University of Iowa, Iowa City, 1930.

33. Hopkins, L. T., "Curriculum Principles and Practices", Sanborn Company, 1929, Pp. 564-604.

34. Indianapolis Public Schools: "Course of Study in Mathematics for the Junior High School Division of the Secondary Schools, Grades 7-8-9", Board of School Commissioners, Indianapolis, Indiana, 1934.

35. Jacobs, L. B., "Eighteen Criteria for Choosing New Textbooks", The Clearing House, Volume II, Number 8, April, 1937 .

36. Jensen, F. A., Correct Practices in Selecting Textbooks, "The Textbook in American Education", Thirtieth Yearbook, Part II, 1931.

37. Jensen, F. A., "Current Procedure in Selecting Textbooks", J. B. Lippencott Company, 1931.

38. Jensen, F.A., "The Selection of Manuscripts by Publishers", National Society for the Study of Education, Thirtieth Yearbook, Public School Publishing Company, Bloomington, Illinois, 1931, Pp. 80-91.

39. Jensen, M. B. and Schrodt, Mable, "Language Difficulty and Learning: The Relative Effectiveness of a Series of Study Sheets of Graded Difficulty as Teaching

Devices with Children in the 6A Grade", Junior Genetic Psychology, Volume XLIX, Number 2, December, 1936. 
40. Knight, F. B., "Some Consideration of Method", National Society for the Study of Education, Twentyninth Yearbook, Part II, Public School Publishing Company, Bloomington, Illinois, 1930, P. 224.

41. Kramer, G. A., "The Effect of Certain Factors in the Verbal Arithmetic Problems upon Children's Success in their Solution", The John Hopkins University Press, Baltimore, Maryland, 1933.

42. Iide, E. S., "Instructor in Mathematics", U. S. Department of the Interior, Office of Education, Monograph Number 23, 1932, Number 17.

43. Long Beach City School, "Mathematics Course of Study for ' $Z$ ' Groups in Grades 7 and 8", Long Beach, California, December, 1928.

44. Los Angeles Educational Research Bulletin, Volume $X$, october, 1930, Series of Articles on the "Evaluation of Textbooks".

45. Louisville Public School, "Mathematics-ontative Course of Study for Junior High School, Grades VIIVIII", Louisville, Kentucky, 1933.

46. Lucklesh, M. and Moss, F. K., "Seeing, A Partnership of Lighting and Vision", Wiliiams and Wilkins Company, Baltimore, Maryland, 1931.

47. Maxwell, C. R., "The Use of Score Cards in Evaluating Textbooks", National Society for the study of Education, Thirtieth Yearbook, Part II, Public School Publishing Company, Bloomington, Illinois, 1931, Pp. 143-146.

48. McCormick, Clarence, "The Teaching of General Mathematics in the Secondary Schools of the United States, Teachers College, Columbia University, Contributions to Education, Number 386.

49. Mead, D. C., "The Best Method of Selecting Textbooks", Educational Administration and Supervision, 4:61-69, February, 1918.

50. Morrison, J. C., "The Use of Textbooks", University of The State of New York, 1933.

51. National Committee on Mathematical Requirements, "Reorganization of Mathematics in Secondary Schools", Houghton Mifflin Company, 1927, P. 171. 
52. National Society for the Study of Education, "Report of the Society's Committee on Arithmetic", Twentyninth Yearbook, Public School Publishing Company, Bloomington, Illinois, 1930 .

53. National Society for the Study of Education, "The Textbook in American Education", Thirtieth Yearbook, Part II, 1931.

54. Oakland Public Schools, "Mathematics for Junior High Schools", Superintendent's Bulletin, Course of Study Serles Number 103, Board of Education, Oakland, California, March, 1927.

55. Ot1s, E. M., "A Textbook Score Card", Journal of Educational Research, 7:132-136, February, 1923.

56. Patty, W. W. and Painter, W. I., "Improving our Method of Selecting Textbooks", Journal of Educational Research, 24:23-32, June, 1931.

57. Patty, W. W., "The Textbook and Its Vocabulary", Journal of Educational Research, Volume 34, Number 24, June, 1931, Pp. 142-145.

58. Progressive Education Association, "Mathematics", Report of Work in Evaluation by the Mathematics Group Participating in the Progressive Education Summer Institute, held at Columbus Ohio, June 22 to July 29, 1936, Ohio State University, Columbus, Ohio, 1936.

59. Rader, L. W., "Scientific Selection of School Texts", Fourth Yearbook, National Education Association: Department of Elementary School Principals, 1925, Pp. 298-304.

60. Repp, A. C., "Mixed Versus Isolated Drill Organization", National Society for the Study of Education, Twentyninth Yearbook, Part II, Public School Publishing Company, Bloomington, Ilinois, 1930, P. 535.

61. Rugg, Harold, "Curriculum-making via National Committees", National Society for the Study of Education, Twenty-sixth Yearbook, Public School Publishing Company, Bloomington, Illinois, 1927, P. 65.

62. Rutledge, R. E., "Administrators Consider Textbook Selection", Nation's School, 6:47-48, December, 1930.

63. San Francisco Public Schools, "Mathematics, Junior High School, Grades VII, VIII, and IX", Curriculum Bulletin Number 108, 1927 . 
64. Schaaf, W. L., "Mathematics for Junior High School Teachers", Johns on Publishing Company, New York, 1931.

65. Schorling, Ralph, "The High School Teacher in the Making", The High School Teacher and the Textbook, Edwards Brothers, Ann Arbor, Michigan, 1931.

66. Schorling, Ralph, and Edmonson, J. B., "The Techniques of Textbook Authors", National Society for the study of Education, Thirtieth Yearbook, Part II, Public School Publishing Company, Bloomington, Ilínois, 1931, Pp. 44-45, 47-48.

67. Terman, L. M., "The Measurement of Intelligence", Houghton Miffín Company, 1916, P. 226.

68. Tinker, M. A. and Paterson, D. G., "Studies of Typographical Factors Influencing speed of Reading", Journal of Applied Psychology, Volume XIII, Number 3, June, 1929, P. 212.

69. Thorndike, E. In, "The Psychology of Arithmetic", Macmillan Company, New York, 1924.

70. Thorndike, E. L., "The Teacher's Work Book", Bureau of Publications, Teachers College, Columbia University, New York, 1927 .

71. University of the State of New York, "A Tentative Syliabus in Junior High School Mathematics", The University of the State of Now York Press, Alvany, 1928.

72. Weber, O. F., "Methods Used in the Analysis of Textbooks", School and Society, November 27, 1926, Pp. 678684.

73. Whipple, Guy M., "The Selection of Textbooks", American School Board Journal, 80:51-53, 158, May, 1930.

74. Williams, L. A., "A Rating Scale by Which Teachers Are to Select Textbooks", Oakland, California School Department, 1929.

75. Williams, R. I., "The Selection of Mathematic Texts in the Junior High School", School Science and Mathematics, 31:284-291, March, 1931. 